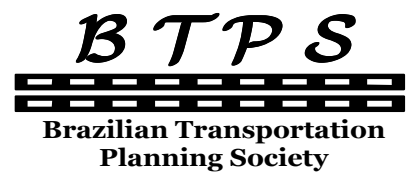

Journal of Transport Literature

Vol. 7, n. 2, pp. 403-430, Apr. 2013

Research Directory

\title{
Driver and vehicle type parameters' contribution to traffic safety in UAE
}

[A contribuição dos parâmetros de motorista e tipo de veículo para a segurança do tráfego nos Emirados Árabes Unidos]

\author{
Sharaf A. Alkheder*, Reem Sabouni, Hany El Naggar, Abdul Rahim Sabouni \\ ALHOSN University, United Arab Emirates, ALHOSN University, United Arab Emirates, \\ University of New Brunswick, Canada, ALHOSN University, United Arab Emirates
}

Submitted 31 Jul 2012; received in revised form 9 Sep 2012; accepted 10 Sep 2012

\begin{abstract}
Former traffic safety studies showed clearly that driver or human factor is a major contributor to road accidents. Hence, to better understand the traffic accident nature it's so vital to analyze all characteristics related to drivers involved in these accidents. This article focuses on this aspect through using a dataset representing UAE traffic accidents in the time interval between 2007 and 2010. A major focus was given in this article to analyzing the relation between traffic accidents and driver citizenship for all types of involved vehicles. This was due to the fact that drivers in UAE came from different backgrounds (over than 100 citizenships) and hence it's so important to identify citizenships with major involvement in road accidents for each vehicle type. This will allow traffic authorities to give special attentions to these citizenships and vehicle types through special traffic awareness programs, fining system or other preventive measures aiming to reduce the accidents frequency and severity levels. Results indicated that for all types of vehicles emirates nationals drivers represent the citizenship with the highest involvement rate in traffic accidents $(30.02 \%)$ followed by Pakistanis $(21.26 \%)$ then comes the Indians drivers with a percentage of $11.95 \%$. Light vehicle type traffic accidents statistics shows that a general trend can be seen for all citizenships where there is an increase in the number of traffic accidents over the course of the three years. The main contribution of the paper is its uniqueness in analyzing such accidents database after the implementation of the new unified traffic law in UAE.
\end{abstract}

Key words: traffic accidents, driver, citizenship, vehicle type, United Arab Emirates.

\section{Resumo}

Estudos anteriores de segurança de tráfego mostraram claramente que o motorista ou o fator humano é um dos principais contribuintes para acidentes de trânsito. Assim, para melhor compreender a natureza do acidente é crucial analisar todas as características relacionadas aos motoristas envolvidos nos mesmos. Este artigo aborda esse aspecto por meio da utilização de um conjunto de dados representativos dos acidentes de trânsito dos Emirados Árabes Unidos no período entre 2007 e 2010.0 foco principal do artigo é analisar a relação entre acidentes de trânsito e a cidadania de origem do motorista para todos os tipos de veículos envolvidos. Isso se deve ao fato de que os motoristas nos Emirados Árabes Unidos são de origens diferentes (mais de 100 nacionalidades) e, portanto, torna-se muito importante identificar cidadanias com maior envolvimento em acidentes de trânsito para cada tipo de veículo. Propicia-se que as autoridades de trânsito possam dar atenção especial a estas cidadanias e tipos de veículo, por meio de programas especiais de conscientização de trânsito, sistemas de multas ou outras medidas preventivas destinadas a reduzir a freqüência de acidentes e seus níveis de gravidade. Os resultados indicaram que, para todos os tipos de veículos, os motoristas nacionais dos Emirates Árabes representam a cidadania com a maior taxa de envolvimento em acidentes de trânsito (30,02\%), seguido por paquistaneses (21,26\%) e indianos (11,95\%). Estatísticas de acidentes de tráfego com veículos leves mostram uma tendência geral de aumento no número de acidentes para todas as cidadanias. A principal contribuição do trabalho é a sua singularidade na análise do banco de dados desses acidentes após a implementação de uma nova e unificada lei de trânsito nos Emirados Árabes Unidos.

Palavras-Chave: acidentes de tráfego, motorista, cidadania, tipo de veículo, Emirados Árabes Unidos.

*Email: s.alkheder@alhosnu.ae.

\section{Recommended Citation}

Alkheder, S. A., Sabouni, R., Naggar, H. E. and Sabouni, A. R. (2013) Driver and vehicle type parameters' contribution to traffic safety in UAE. Journal of Transport Literature, vol. 7, n. 2, pp. 403-430.

- JTL/RELIT is a fully electronic, peer-reviewed, open access, international journal focused on emerging transport markets and published by BPTS - Brazilian Transport Planning Society. Website www.transport-literature.org. ISSN 2238-1031.

This paper is downloadable at www.transport-literature.org/open-access. 


\section{Introduction}

Over the past few decades developing countries witnessed an excessive growth in population associated with large percentage of car ownership due to economic prosperity and reduction in car prices over time. This increased dramatically the traffic volumes on the street networks and caused - since the rate of increase in car ownership is way faster that the rate of developing new transportation infrastructure - serious traffic problems such as road accidents, traffic jams and excessive time delays. Investigating traffic accidents - as a multi-dimensional problem of engineering, social and legislative nature - is a research priority for most countries in order to reduce both accidents severity and frequency by investigating the three accidents stages: pre-accident, time of accident and post-accident stage. Many developing countries are in the process of developing complete digital databases for traffic accidents with all related attributes to be used in comprehensive analysis aiming to identify mainly the reasons behind traffic accidents and the best countermeasures to reduce the extent of this phenomenon.

A study done by Treat et al. in 1977 showed that human was the major contributor to road accidents (over than $90 \%$ involvement as a contributing factor and $57 \%$ as a single factor) followed by environmental ( $4.7 \%$ as a single factor) and vehicle (2.4\% as a single factor) respectively. Most accidents can be related to aggressive \& faulty driving (see Bener et al., 2004). Young driver deaths represent the majority among different categories of fatalities due to lack of experience and knowledge in traffic safety issues (Malhotra, 1990; Trivedi and Rawal, 2011). Some models (Gregersen and Bjurulf, 1996) can be seen in the literature that were developed to study young driver contribution to road accidents with special attention to their driving behavior. Other studies showed that the physical condition of the driver plays an important role in accidents occurrence (Bekibele et al, 2007). Among these are drug usage (Asogwa, 1980), driver vision problems (Humphries, 1987; Toczolowski et al, 1996; Szlyk, 1995) and driver fatigue (Horne and Reyner, 2000) that were studied extensively in the literature.

Causalities and fatalities in GCC countries from road accidents showed a higher value as compared to developing countries at same levels of car ownership ( Bener and Crundall , 2005; Bener, 2001; Bener and Jadaan, 1992; Jadaan et al, 1992; Bener et al, 2003). Driver 
behavior plays a major role in these accidents and hence needs an in depth investigation to identify and quantify the extent of the problem in order to put realistic and effective safety solutions.

The paper is mainly organized into three sections. The first section reviews the UAE road accidents over the past decade and its relationship to the drive licensure. Then another section is introduced to discuss the characteristics of the involved drivers in road accidents with a major focus on the role of driver citizenship. Finally, the third section studies the trend of traffic accidents over time especially in the period following the implementation of the unified traffic law.

\section{UAE Accidents and Driver Licensing}

Driver has a very important role in traffic accidents and most of the time he/she holds the major responsibility as he/she has the highest control level on the road. In the coming sections we focus on identifying the relationships that drivers' licensing, drivers' citizenships and vehicle types have with traffic accidents. Reviewing the statistics related to driver licensing over the past 11 years from 2000 to 2010 (Figure 1) reveals that the total number of driver's licenses issued over these years has increased significantly reaching a total number of about 496138 in 2009 while it was 262045 in 2000 . The majority of these licenses are issued for the first time (new licenses especially after 2003) while the rest are renewals. The large number of newly issued licenses can be related to traffic accidents in that most of new license holders are usually lack the driving experience which increase the risk of getting involved in a traffic accident.

From these statistics we calculated the average number of licenses per accident, per fatality and per injury (Figure 2). As can be seen from the figure, the average number of licenses per accident, per fatality and per injury is increasing over time with the rate for fatality being the highest. This match the increase in the total numbers of issued licenses. However in order to understand the real trend we need to compare these rates to the total number of issued licenses. So we divided these license averages per accident, per fatality and per injury by the total number of licenses. Results show that roughly for accident and injury categories, the average number of licensees associated with each accident/injury is almost constant over 
years. While for fatality, it's clear that the average number of licensees associated with each fatality is decreasing over years which indicate that there is an increase in the accident severity (fatality) over time with more cars being involved in these accidents upon their occurrence.

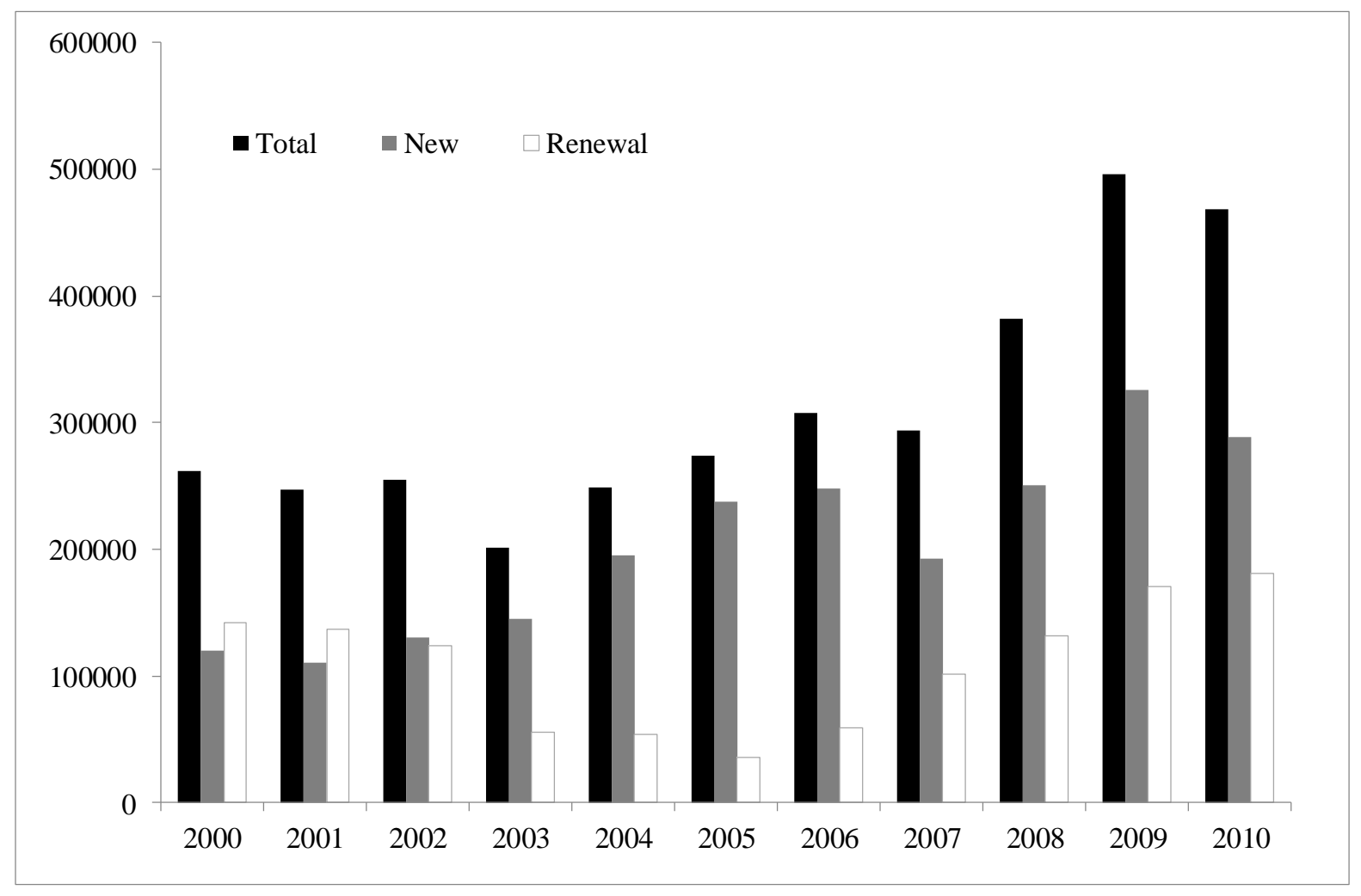

Figure 1 - Total, new and renewed license numbers for 11 year period

Finally, looking at the statistics that is related to the average number of fines per license shows that there is a significant increase in the number of fines issued per license (13 in 2009 and 5 in 2000 on average). This can be related to the large increase in the number of driving licenses issued over the past 11 years (especially new ones) from one side and the higher level of law enforcement from the other side. Statistics relating fines to nationality show that citizens with higher number of fines are also the citizens with higher rates of accidents. For example, overspeeding in UAE represent the major type of fines that is also clearly contribute significantly to traffic accidents with fatalities type. 


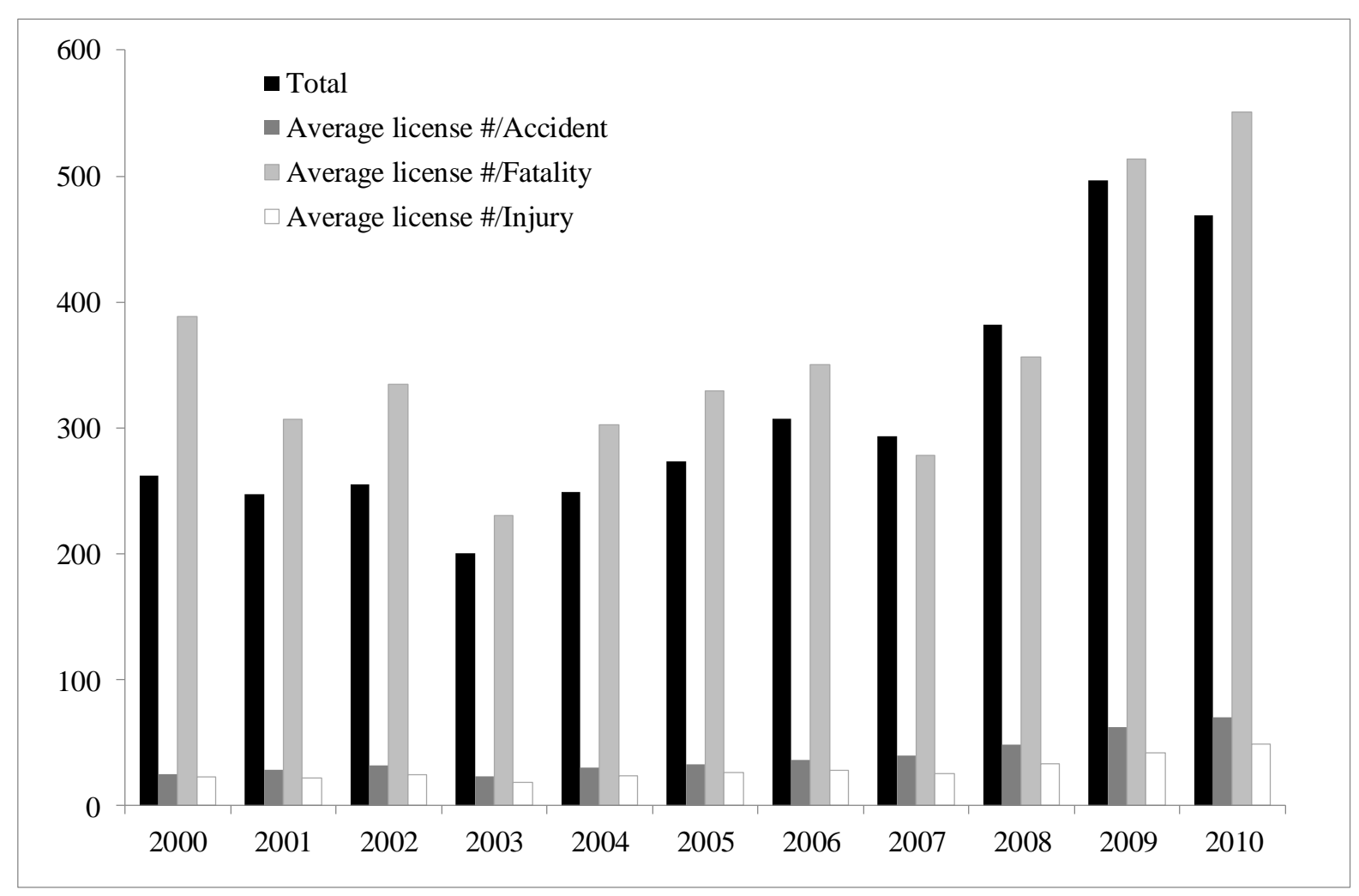

Figure 2 - Average numbers of licenses per accident, per fatality and per injury (Total number is given in thousands)

\section{Drivers' Characteristics and Traffic Accidents}

In-depth analysis is performed to better understand the characteristics of the drivers who are involved in such traffic accidents. Statistics regarding accidents' totals for 4 years (2007, 2008, 2009, 2010) based on the driver/responsible party citizenship for each vehicle type are collected and analyzed. Figure 3 shows the 4 years accidents' (2007-2010) totals and percentages distributed according to the citizenship of the driver for all vehicle types. 


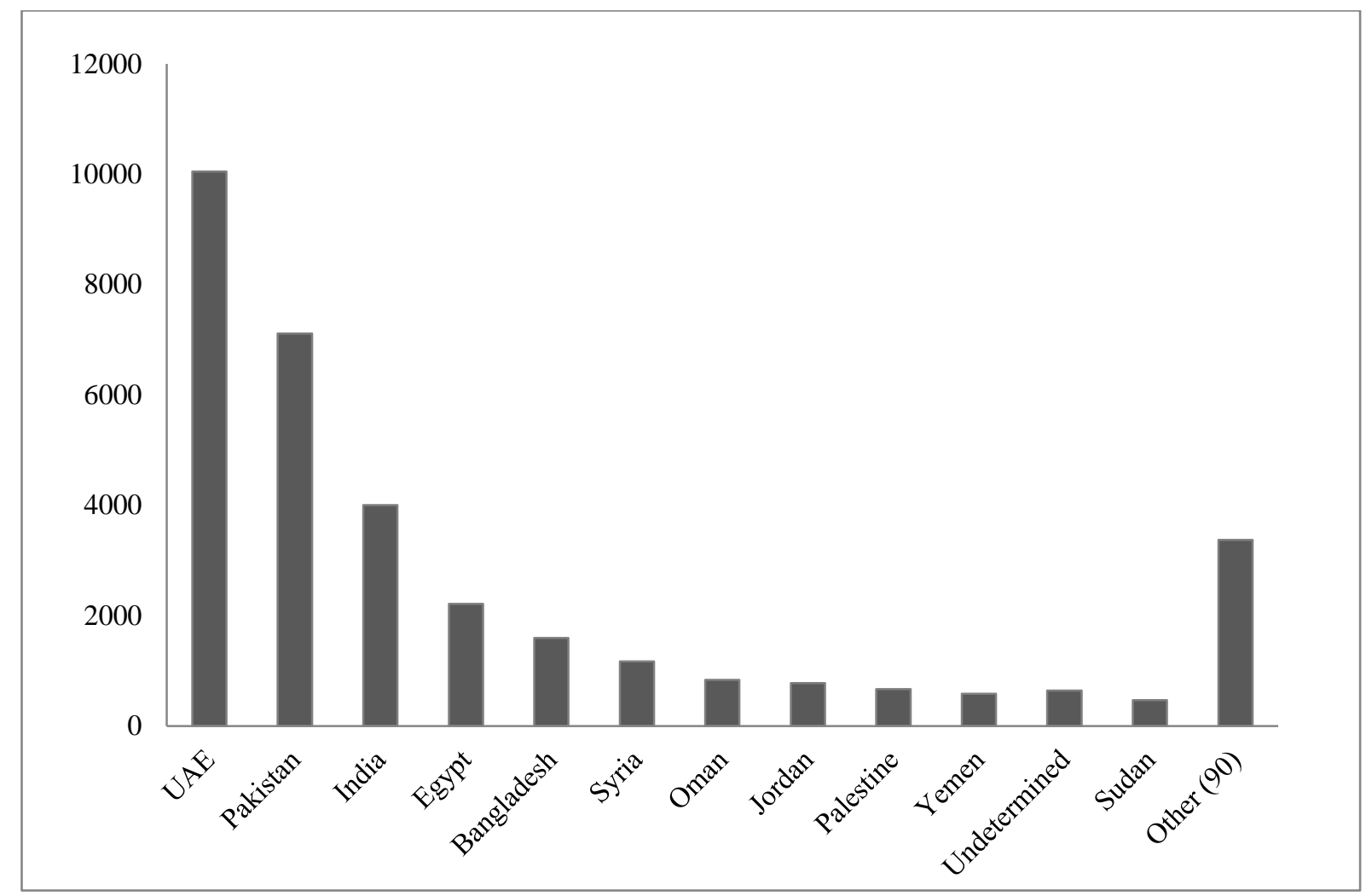

Figure 3a. 4 year accidents' totals distribution according to driver citizenship for all vehicle types.

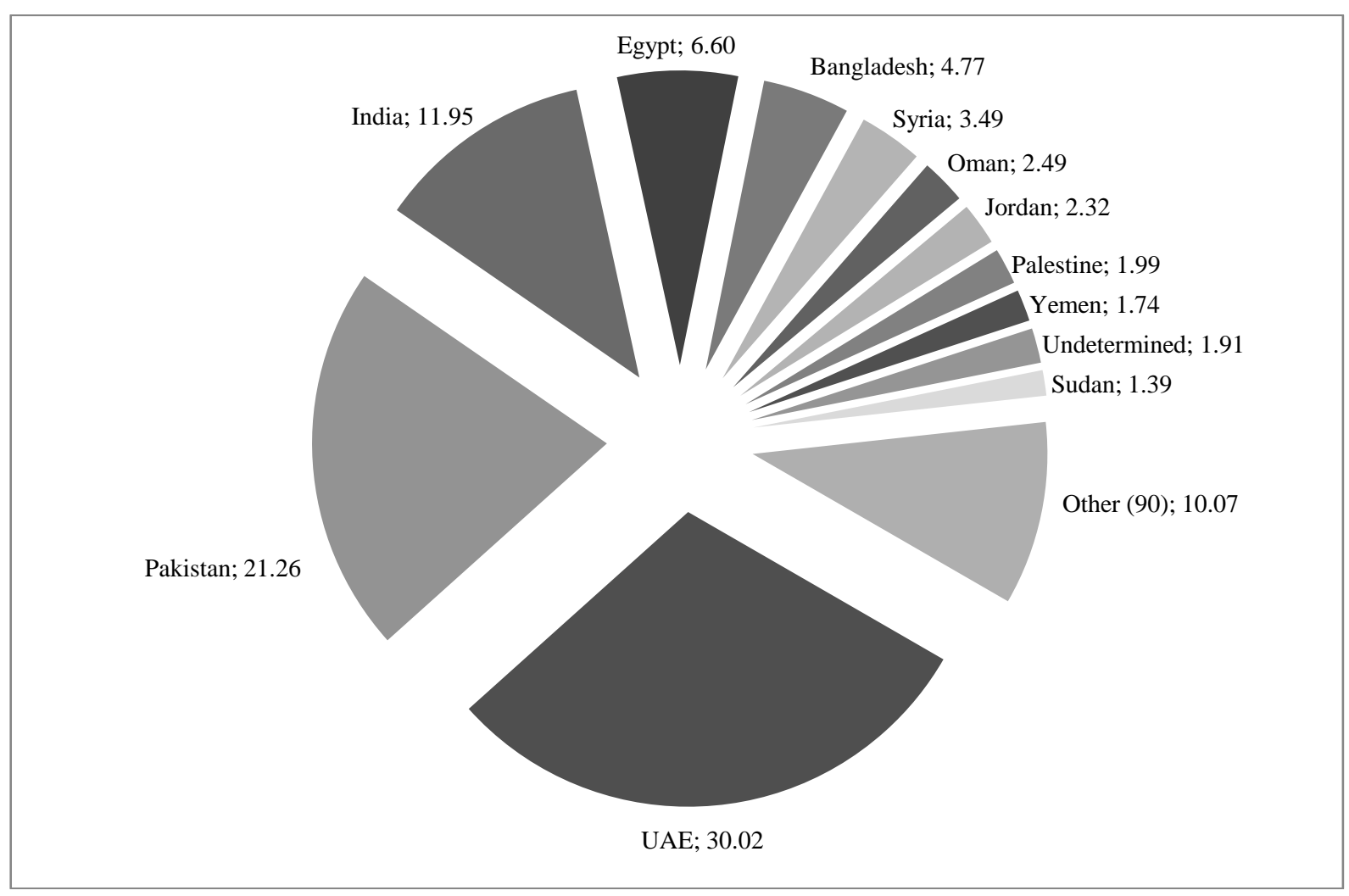

Figure 3b. 4 year accidents' percentage distribution according to driver citizenship for all vehicle types. 
From the results presented in Figure 3, the 4 years accidents' totals and percentages for all types of vehicles show that the highest percentage of accidents was for emirates nationals drivers $(30.02 \%)$ followed by Pakistanis $(21.26 \%)$ then comes the Indians drivers with a percentage of $11.95 \%$. The figure shows also the other 9 citizenships that have a major contribution to traffic accidents while for the rest of citizenships (90 citizenships) their contribution doesn't exceed $10.07 \%$. The fact that many Pakistanis and Indians work as drivers may explain their high percentage of involvement in traffic accidents. A proposal might be to develop a traffic safety trainings and brochures in different languages to increase the traffic safety awareness for different citizenships. Figures 4 to 11 show for each type of vehicle the distribution of traffic accidents according to the driver citizenship. For the light vehicle (Figure 4), emirates nationals, Pakistanis, Indians and Egyptians represent the major citizenships that are involved in traffic accidents for the past four years. For motor cyclists' accidents (Figure 5), emirates nationals, Indians, Egyptians, Bangladeshis, and Pakistanis represent the citizenships with the highest contribution to traffic accidents.

Figures 6 and 7 show the traffic accident distribution results based on citizenship for both light and heavy buses. As expected, the most contribution to accidents for these two types of vehicles is done by Pakistanis and Indians drivers. The same conclusion can be made from Figures 8, 9, and 10 for the traffic accidents that are related to the light mechanical vehicle, heavy mechanical vehicle, and heavy shipment vehicle. This can be interpreted by the fact the Pakistanis and Indians represent the major citizenships that work in these types of industries either in public transportation as drivers, or in construction industries or other heavy industry business. Again, more attention, trainings, workshops and public awareness programs for the highest involved citizenships in traffic accidents need to be developed to reduce their involvement in traffic accidents and hence improve the traffic safety levels. 


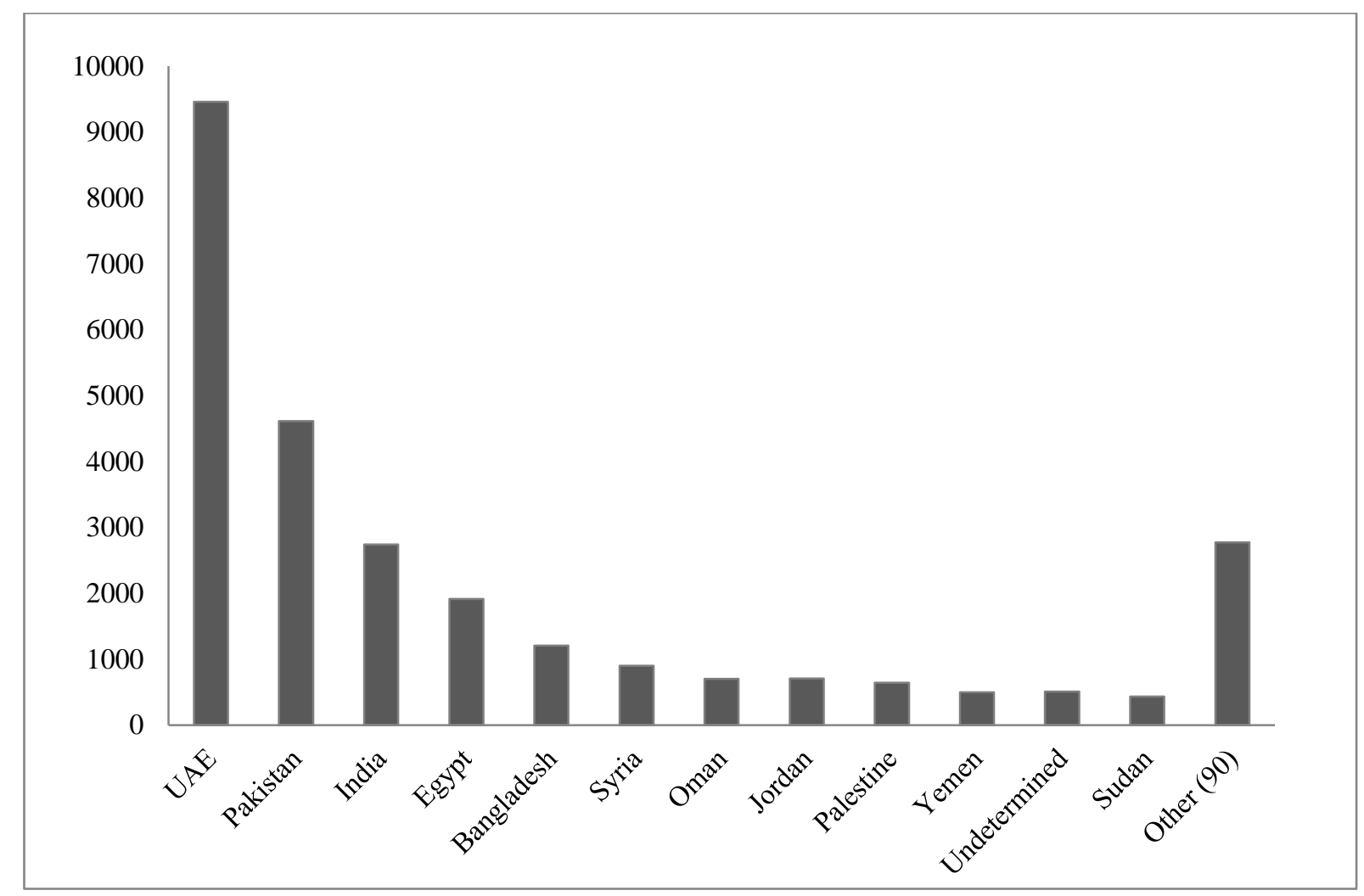

Figure 4. Distributions of traffic accidents according to driver citizenship for light vehicle

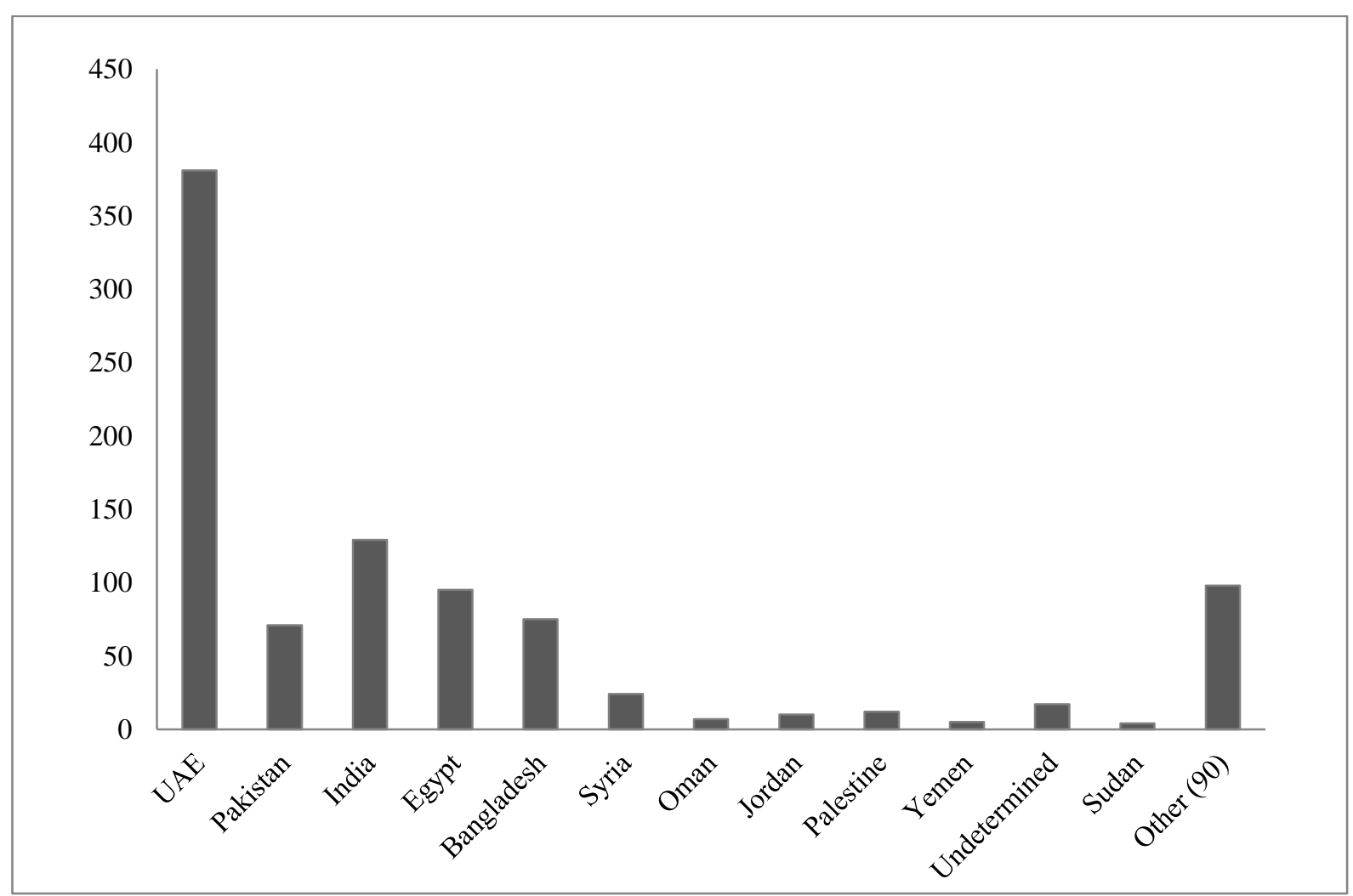

Figure 5. Distributions of traffic accidents according to driver citizenship for motor cyclists 


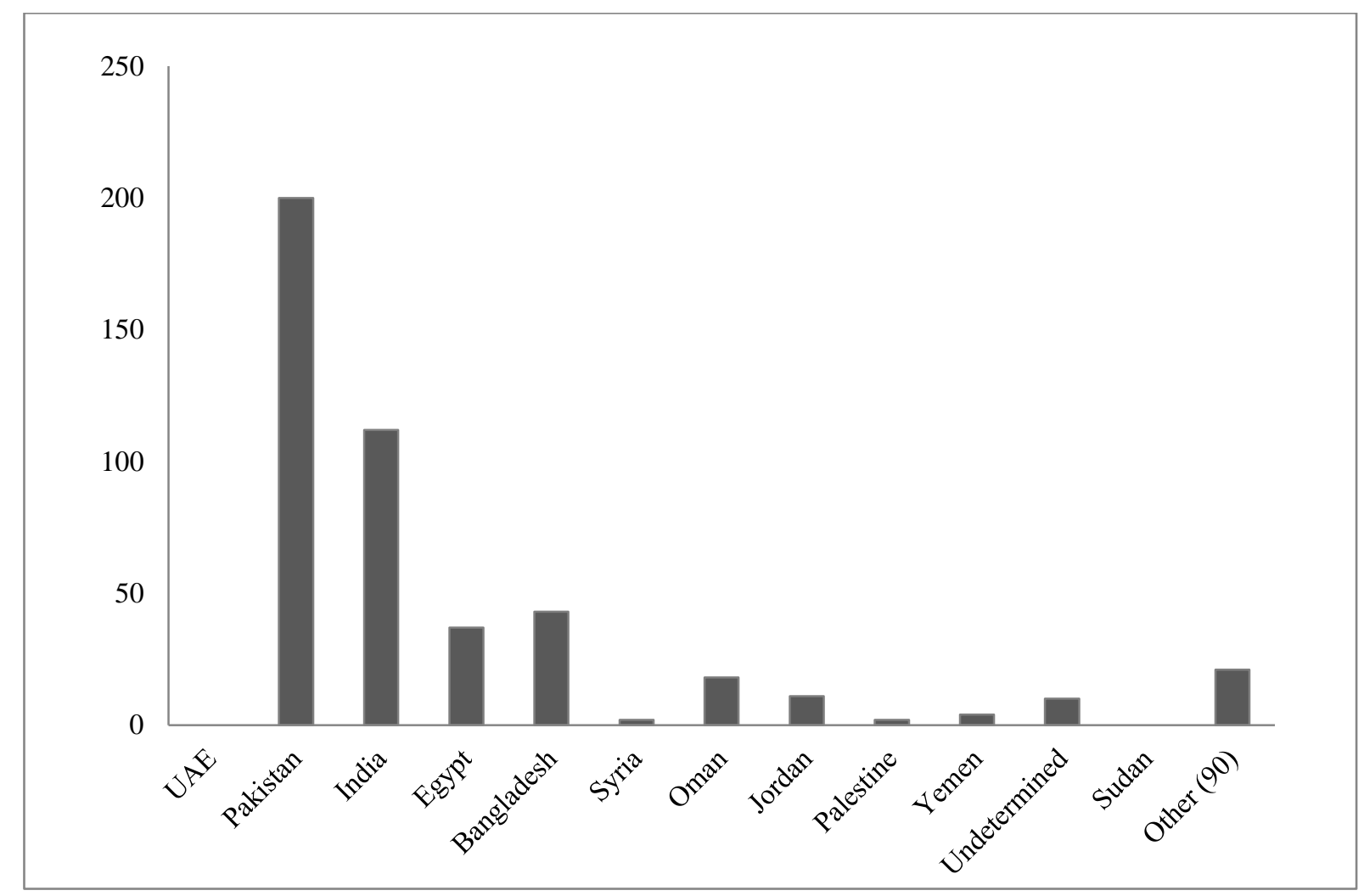

Figure 6. Distributions of traffic accidents according to driver citizenship for light bus

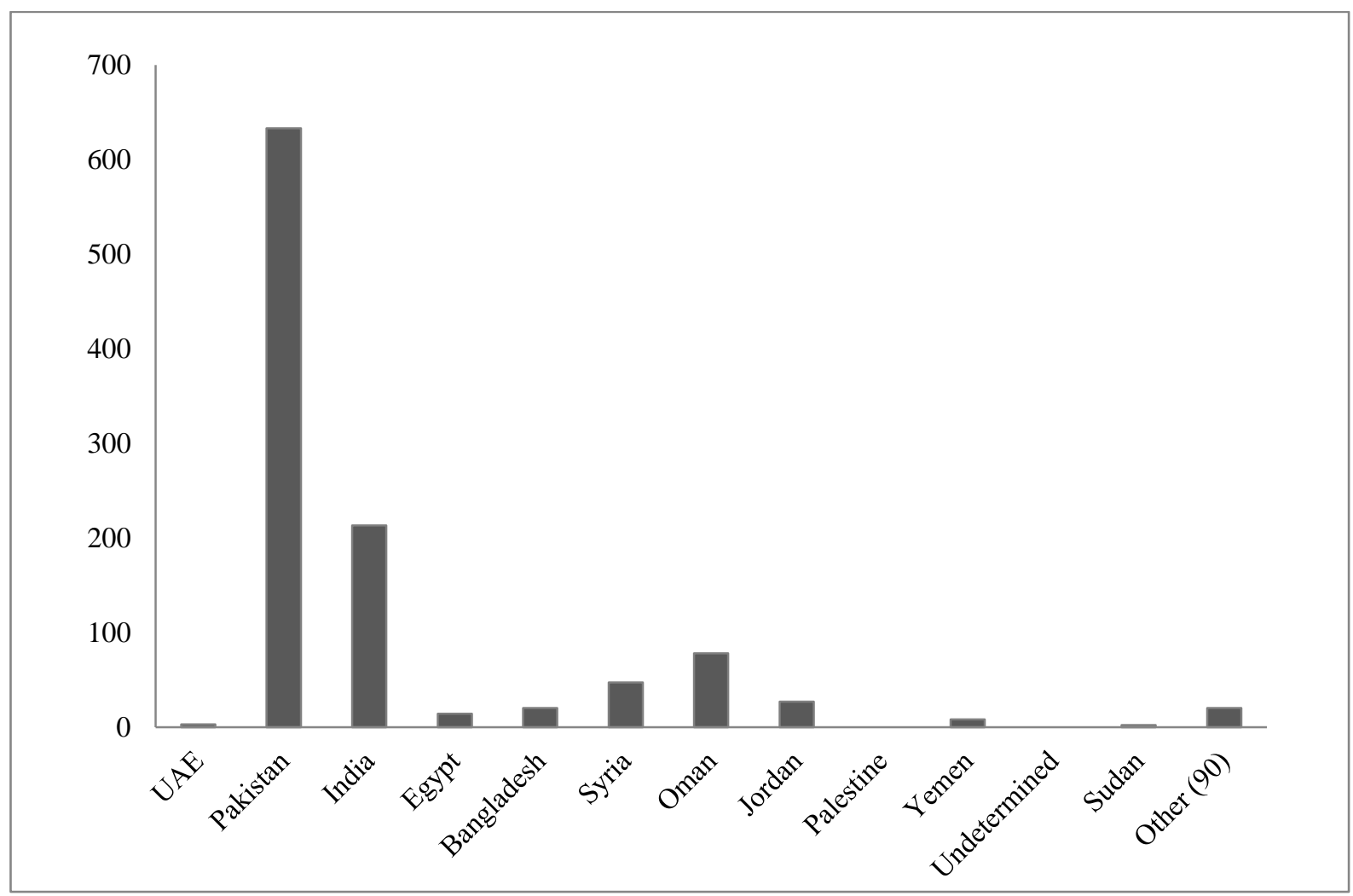

Figure 7. Distributions of traffic accidents according to driver citizenship for heavy bus 


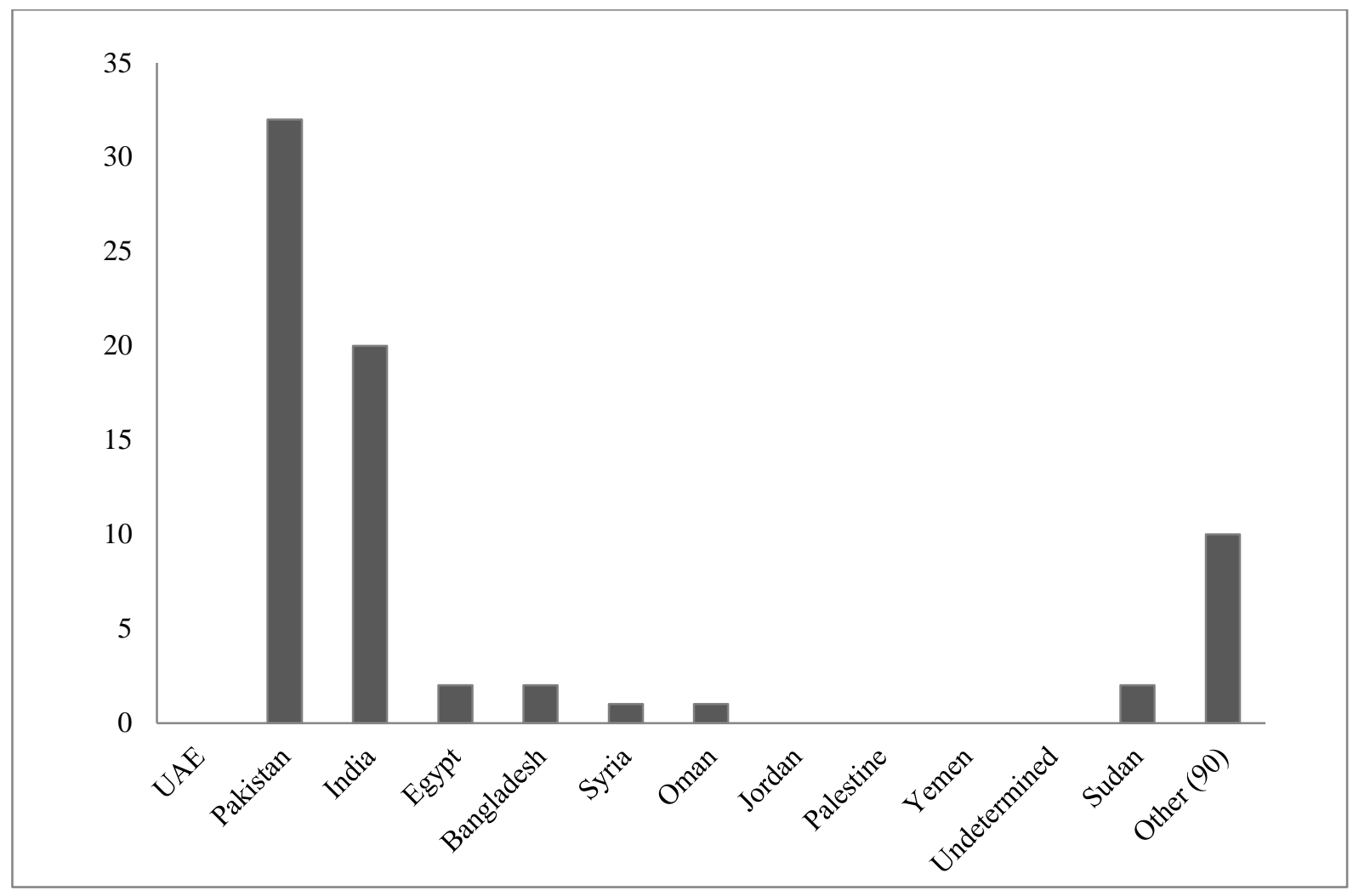

Figure 8. Distributions of traffic accidents according to driver citizenship for light mechanical vehicle

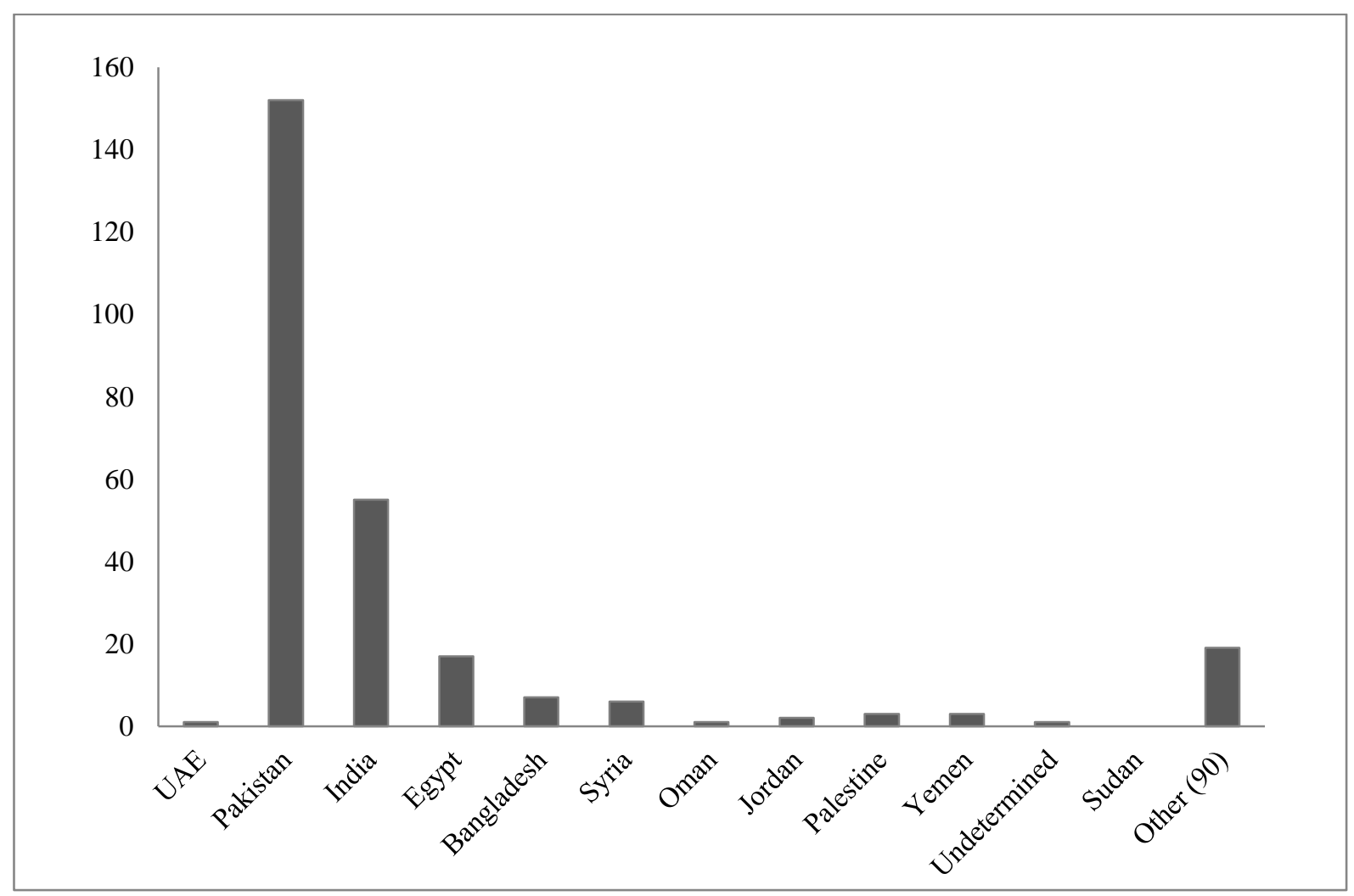

Figure 9. Distributions of traffic accidents according to driver citizenship for heavy mechanical vehicle 


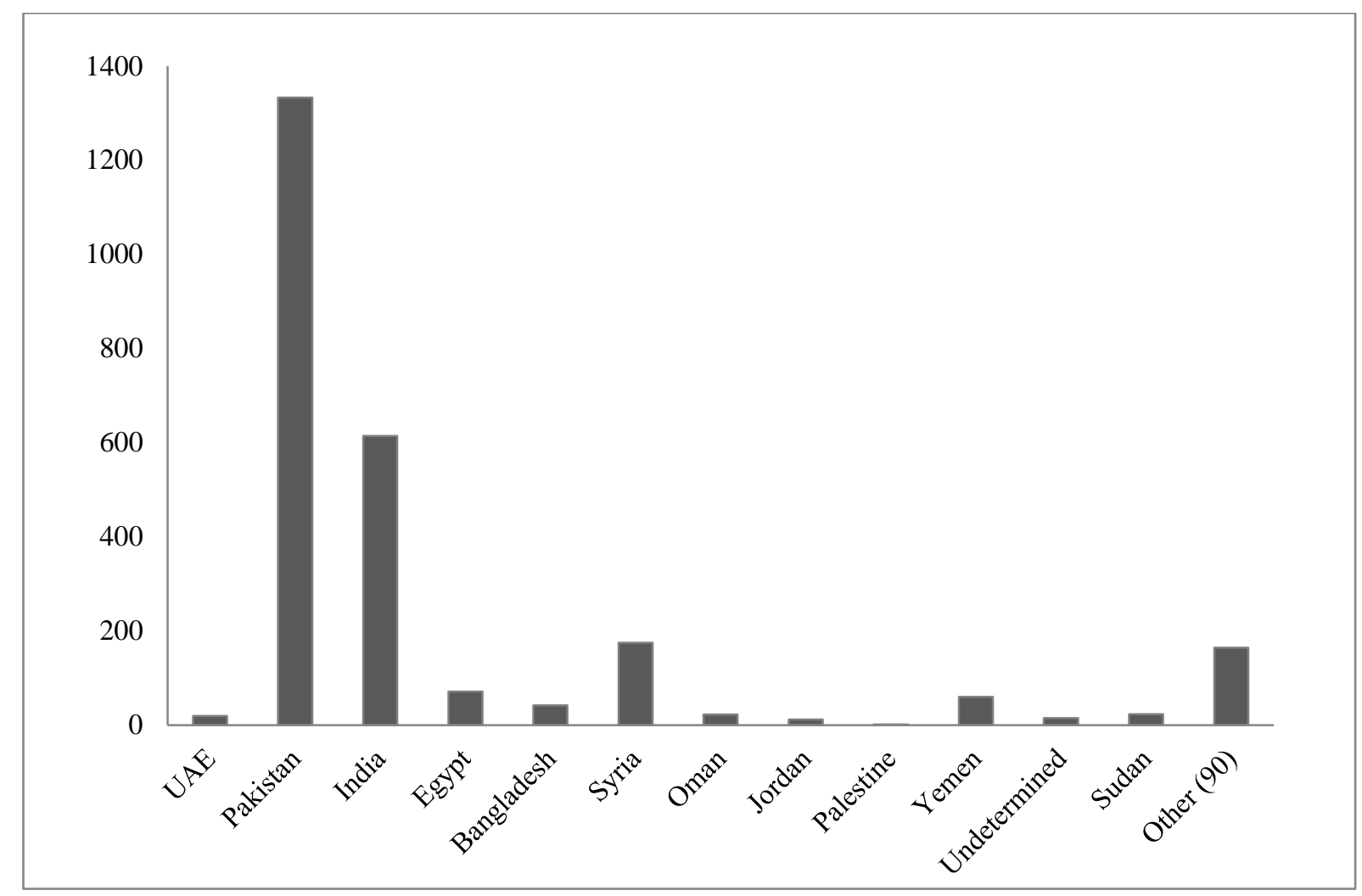

Figure 10. Distributions of traffic accidents according to driver citizenship for heavy shipment vehicle

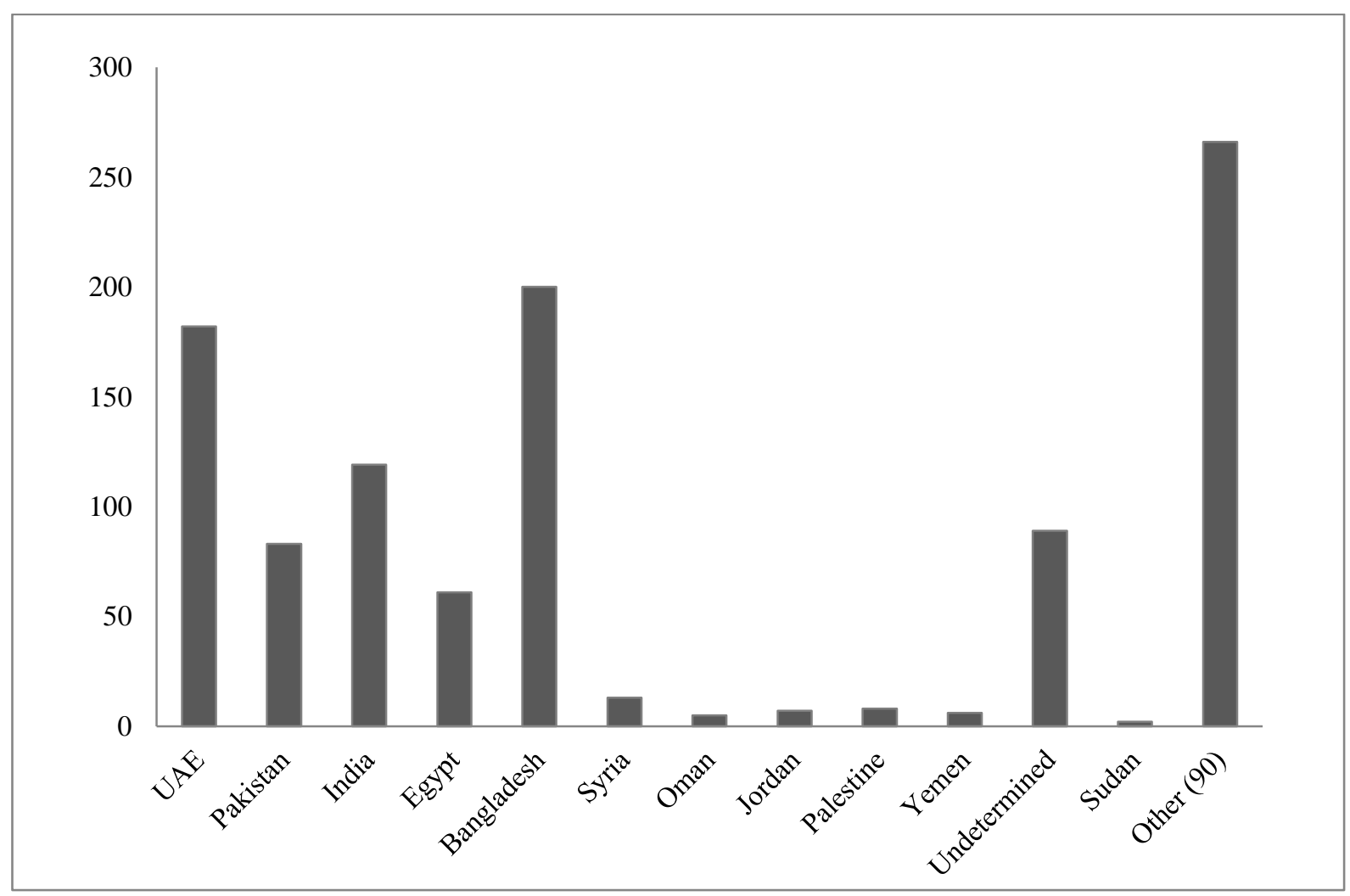

Figure 11. Distributions of traffic accidents according to driver citizenship for undefined vehicle 
Furthermore, accidents' totals and percentages for 4 years $(2007,2008,2009,2010)$ for all citizenships per each vehicle type can be analyzed as shown in Figure 12. Results indicate that most of these traffic accidents are caused by light vehicles (80.93\%) followed by heavy shipment vehicles (7.62\%). More focus on these vehicle types is needed and the reasons behind their high contribution in traffic accidents need to be identified.

Figure 13 shows the distribution of the total four years' accidents per citizenship for all types of vehicles. For the citizenships that have major contribution in traffic accidents, clear trends can be seen. For example, most of the traffic accidents for emirates nationals were concentrated in the light vehicle and motorcycle with the light vehicle accidents composing the highest percentage. Traffic accidents related to light vehicle, heavy shipment vehicle, and heavy bus represent the major types of accidents for Pakistani citizenship while light vehicle and heavy shipment vehicle accidents were the major types for Indian citizenship. For the rest of citizenships, traffic accidents caused by light vehicle dominated all types of vehicles' accidents. 


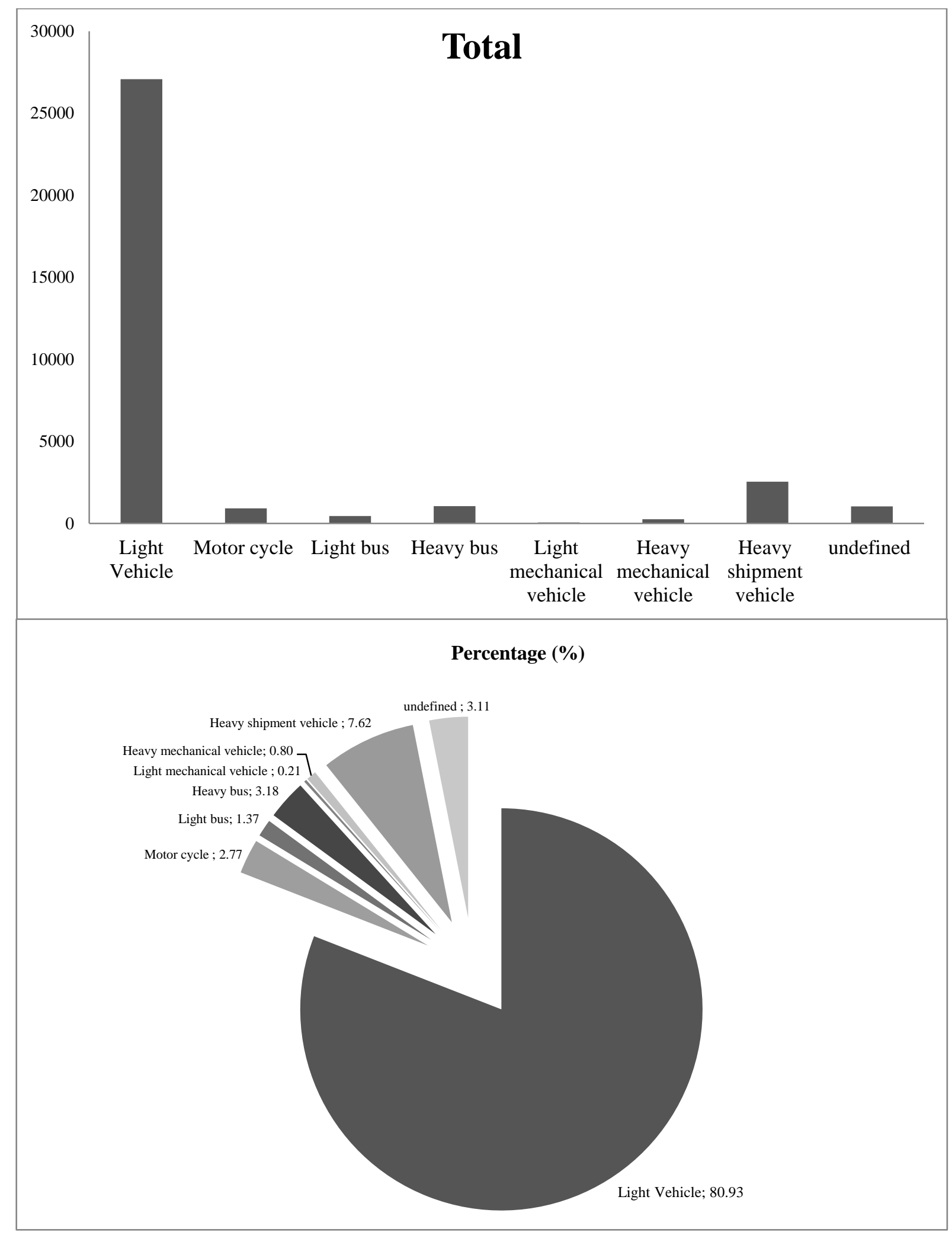

Figure 12. Four years accidents' totals and percentages distributed according to vehicle type for all citizenships 


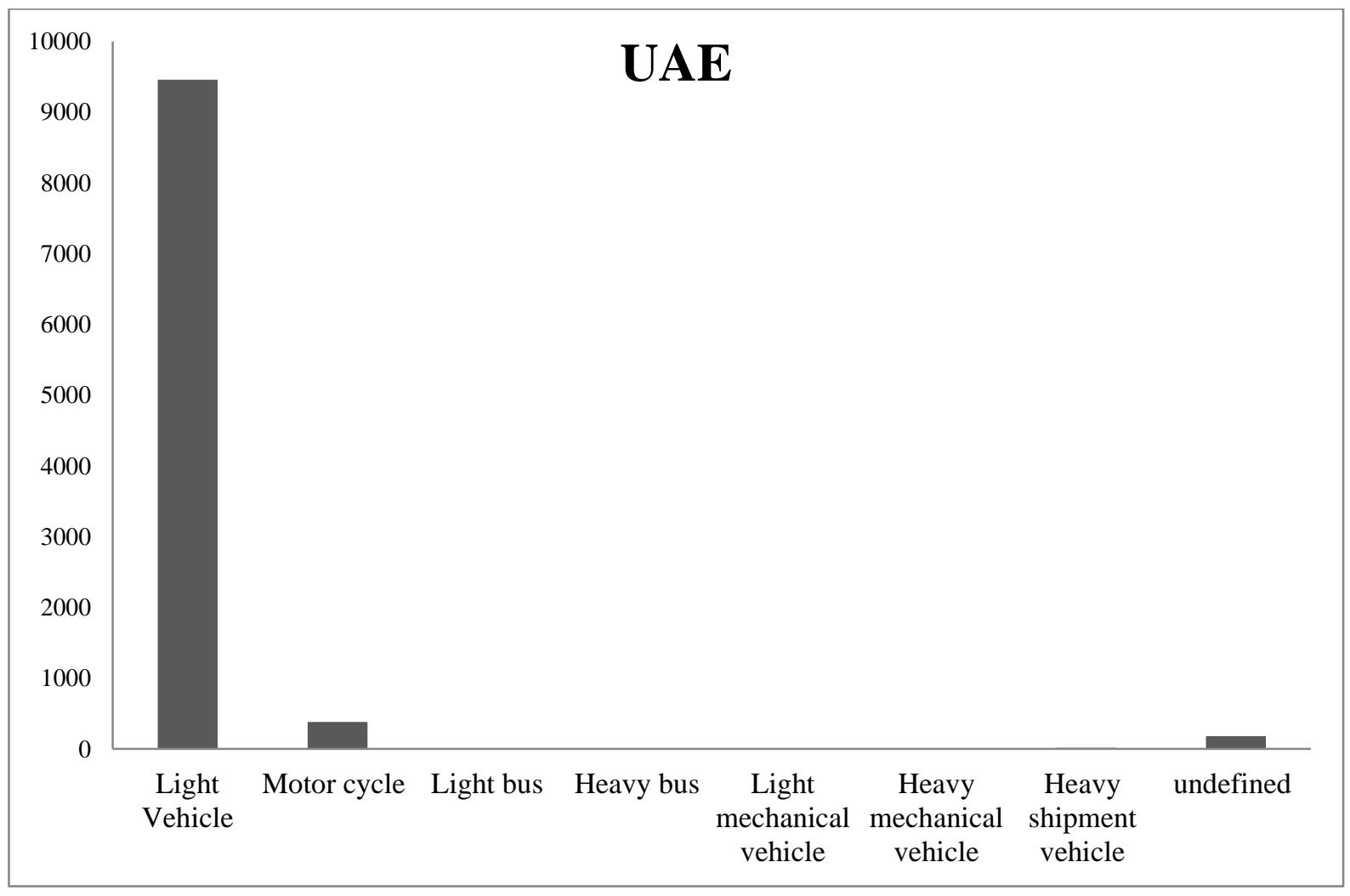

Figure 13 (1). Four years accidents' totals distributed according to citizenship - Emirates citizenship

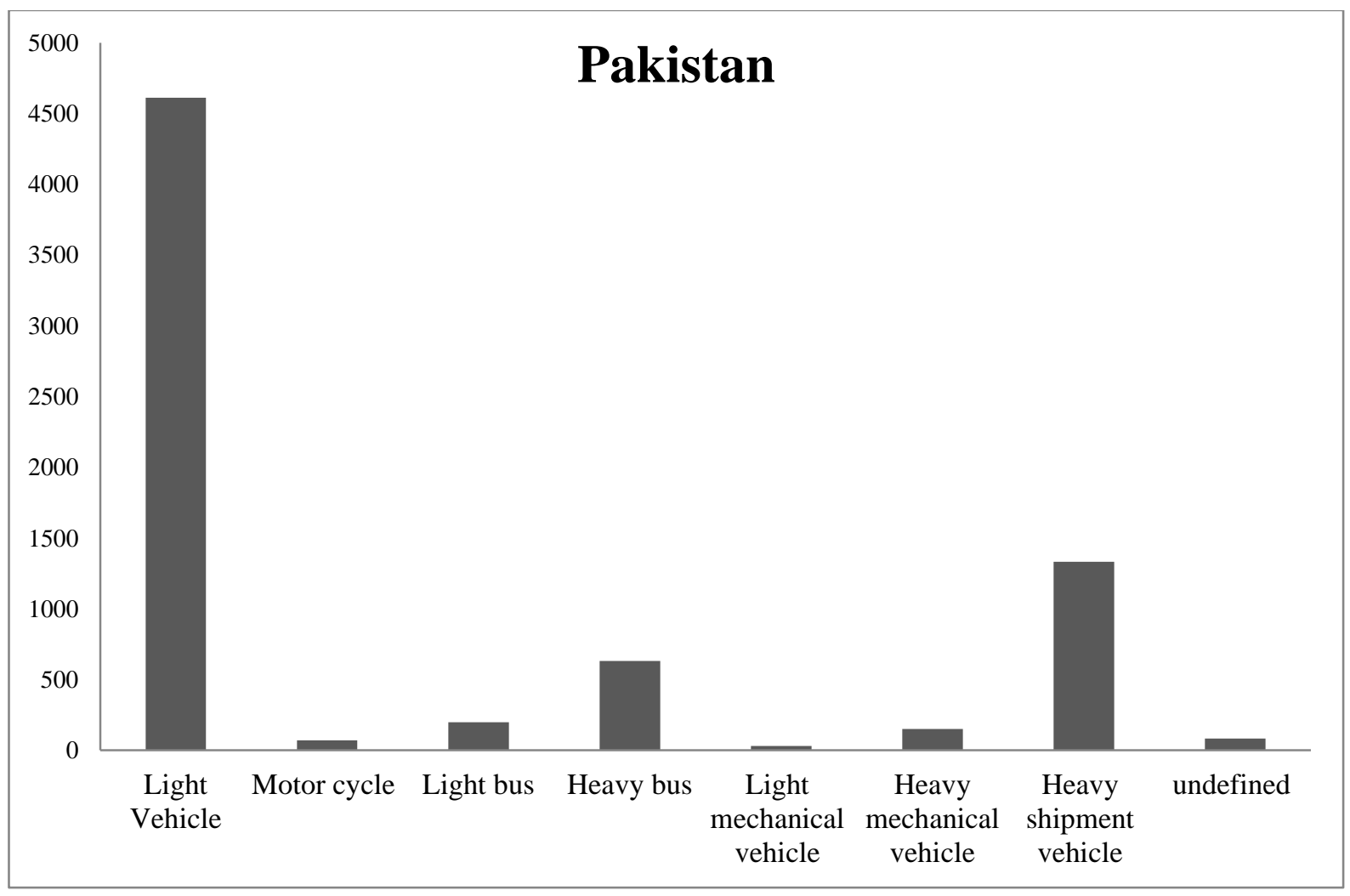

Figure 13 (2). Four years accidents' totals distributed according to citizenship - Pakistanis citizenship 


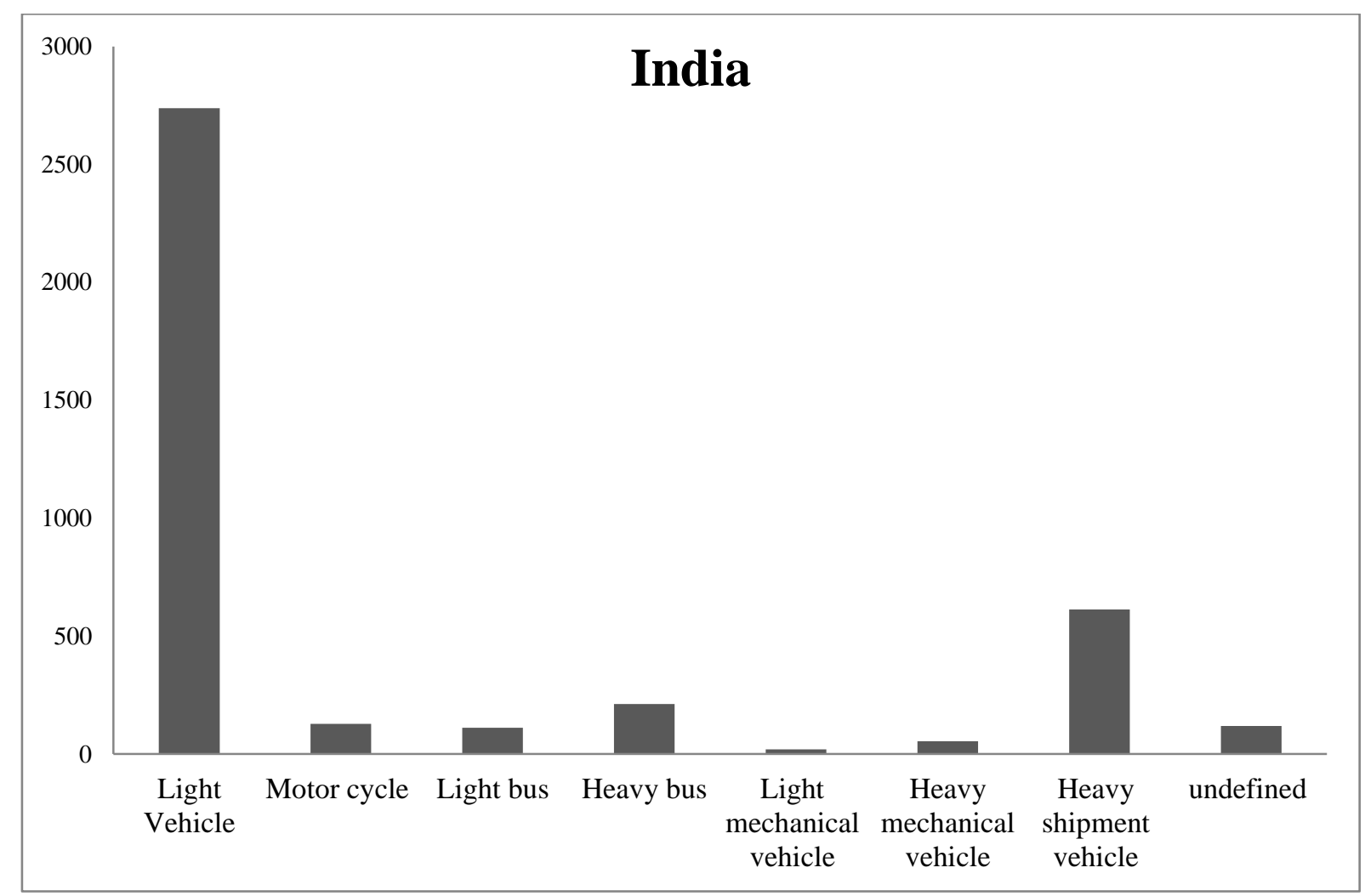

Figure 13 (3). Four years accidents' totals distributed according to citizenship - Indian citizenship

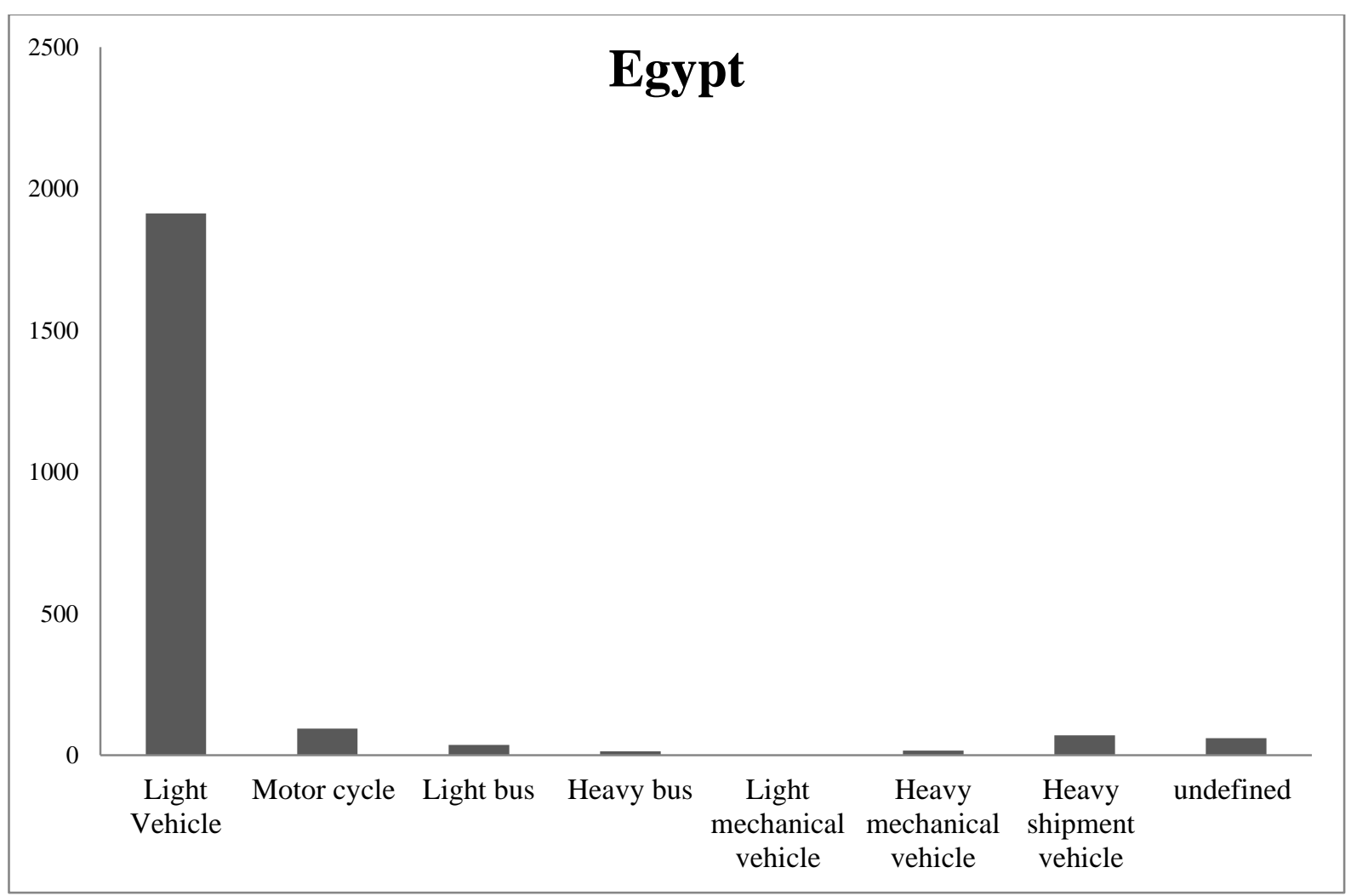

Figure 13 (4). Four years accidents' totals distributed according to citizenship - Egyptian citizenship 


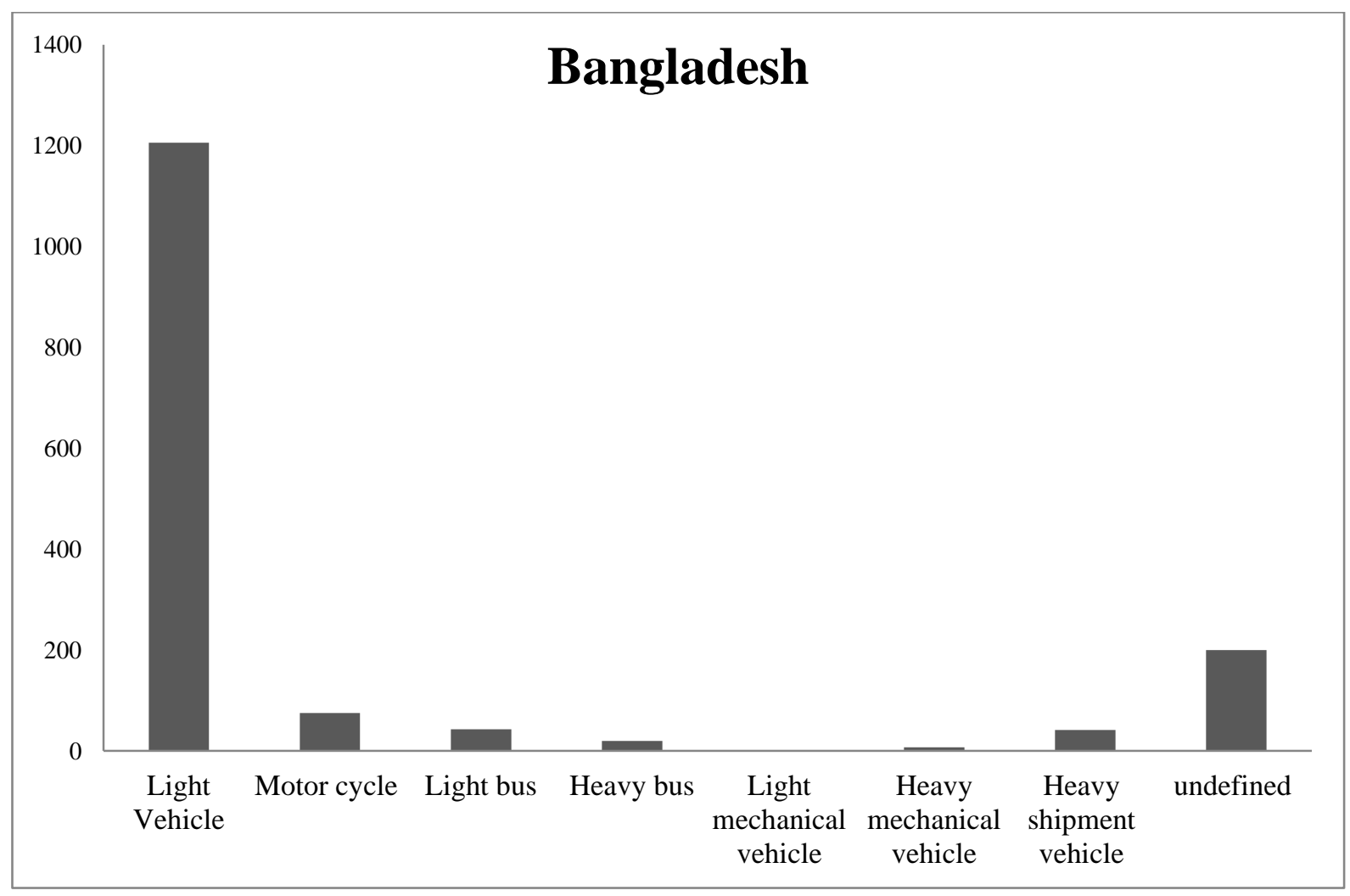

Figure 13 (5). Four years accidents' totals distributed according to citizenship - Bangladeshi citizenship

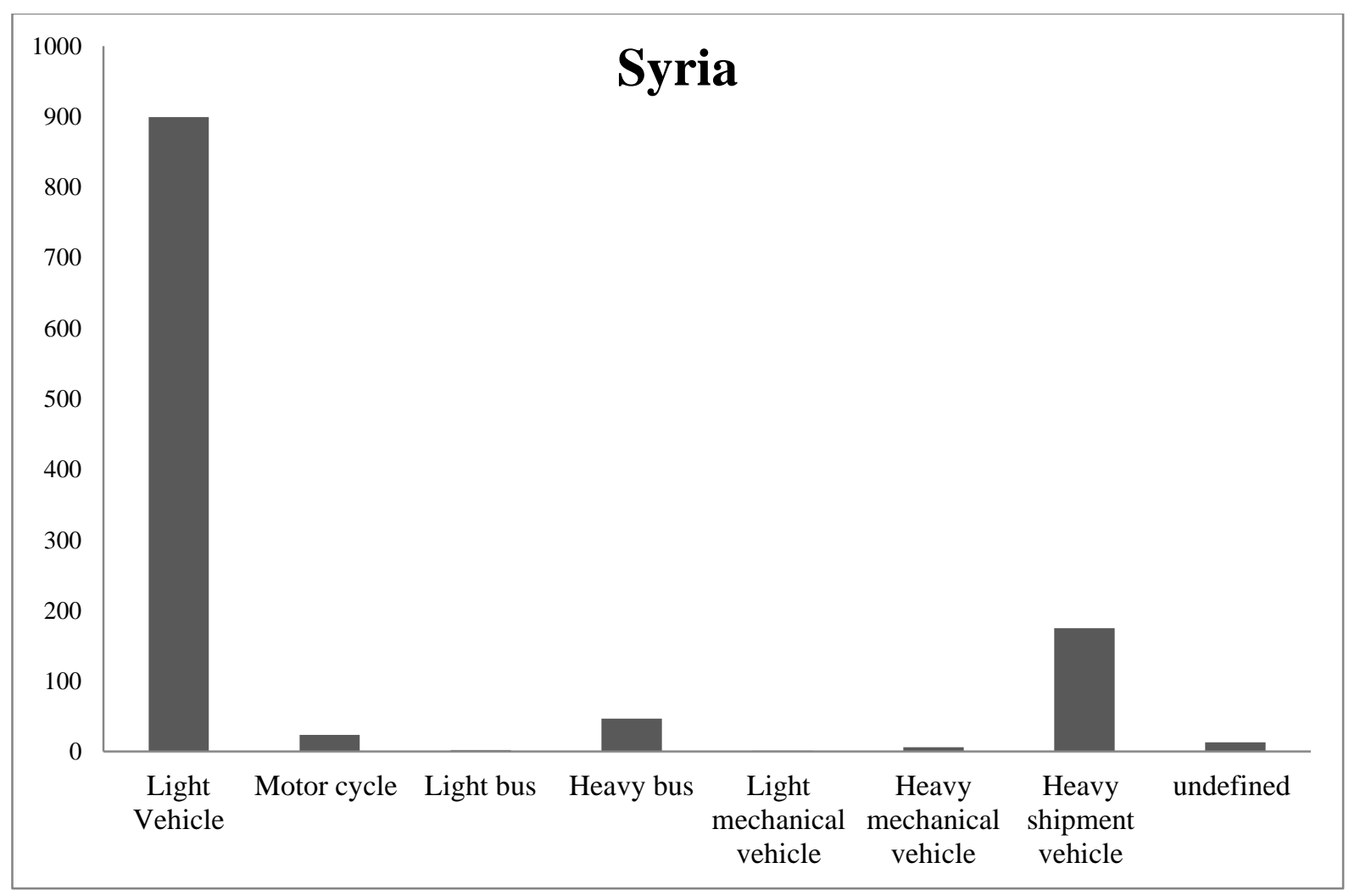

Figure 13 (6). Four years accidents' totals distributed according to citizenship - Syrian citizenship 


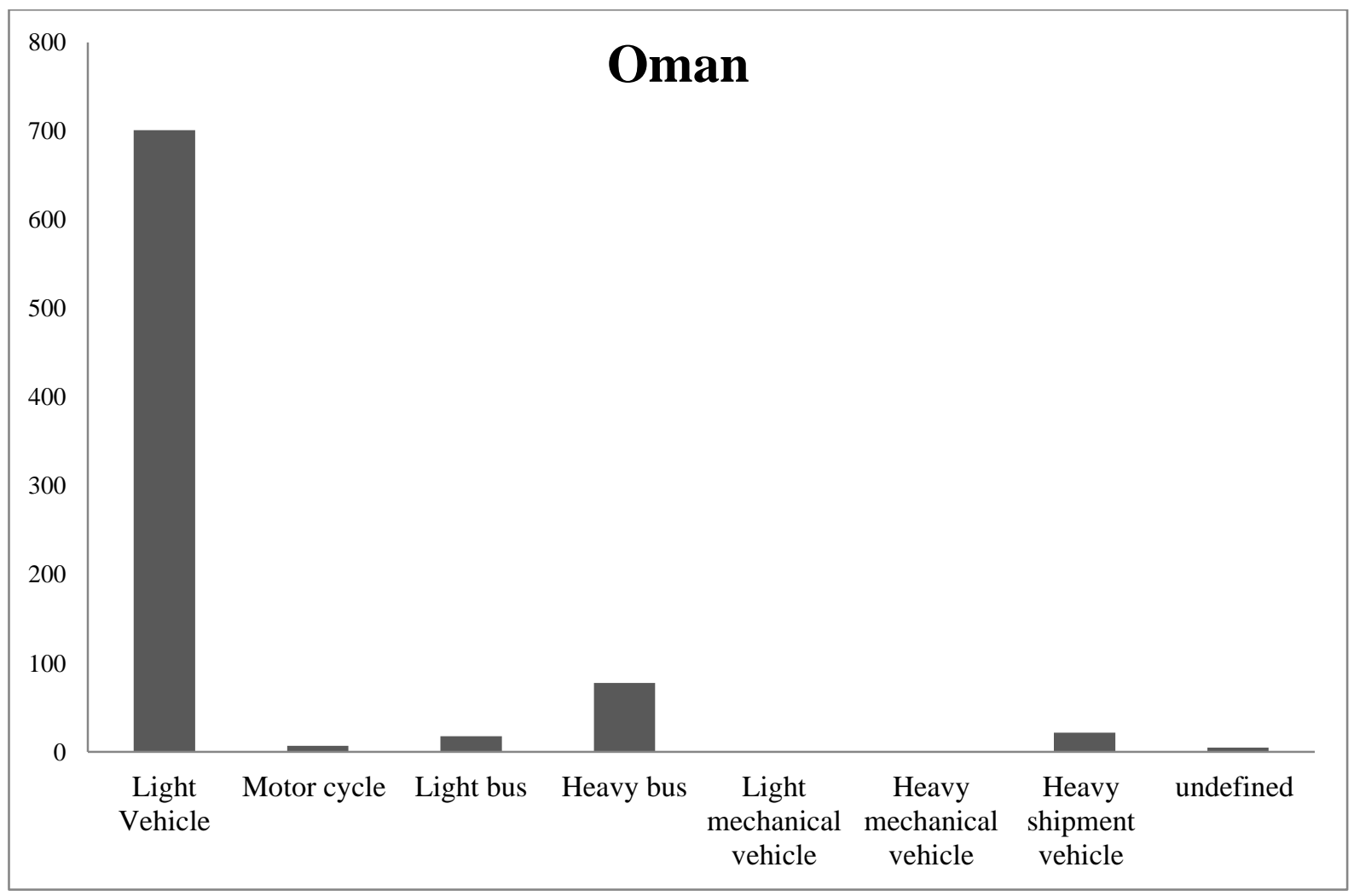

Figure 13 (7). Four years accidents' totals distributed according to citizenship - Omani citizenship

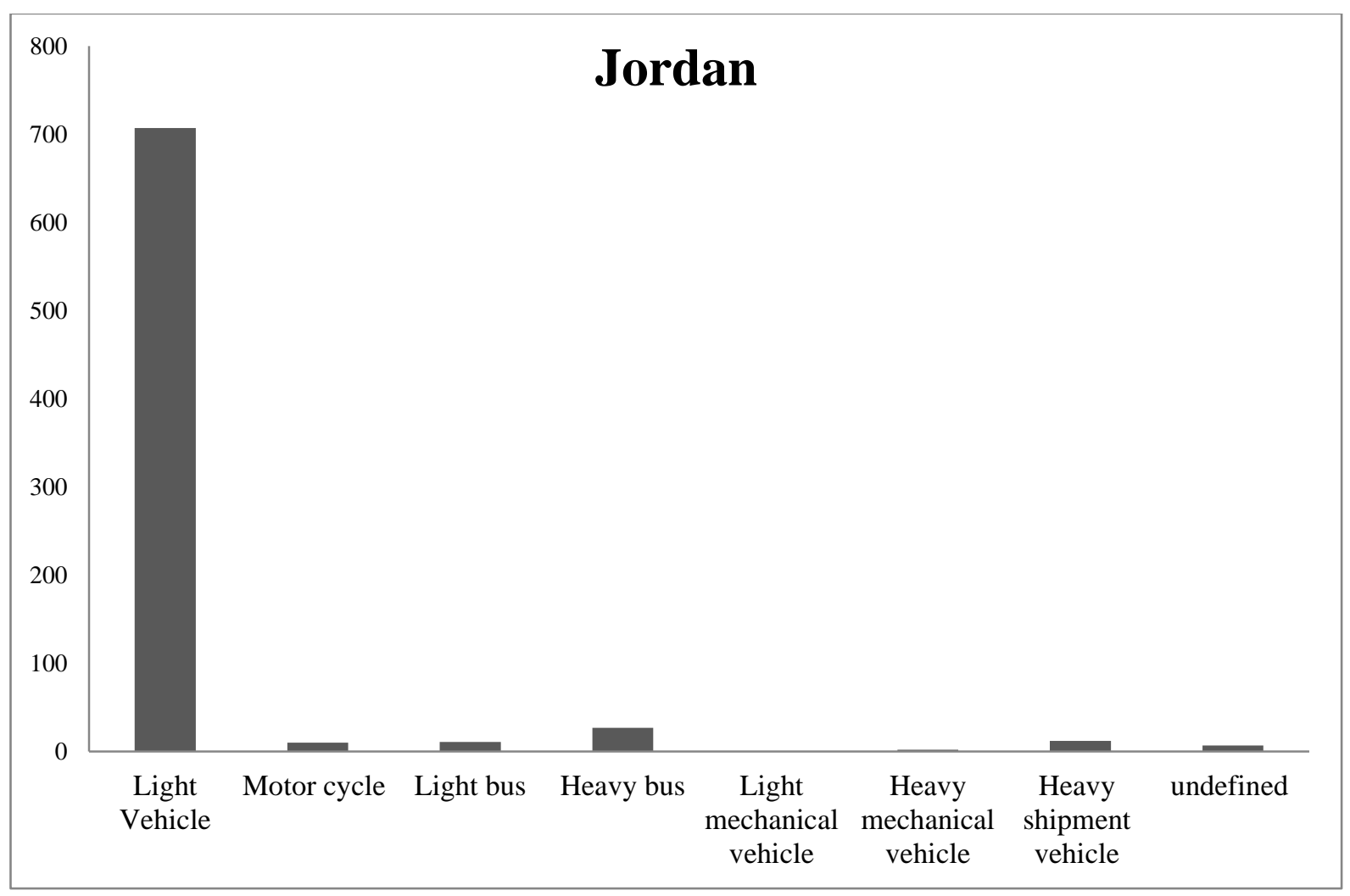

Figure 13 (8). Four years accidents' totals distributed according to citizenship - Jordanian citizenship 


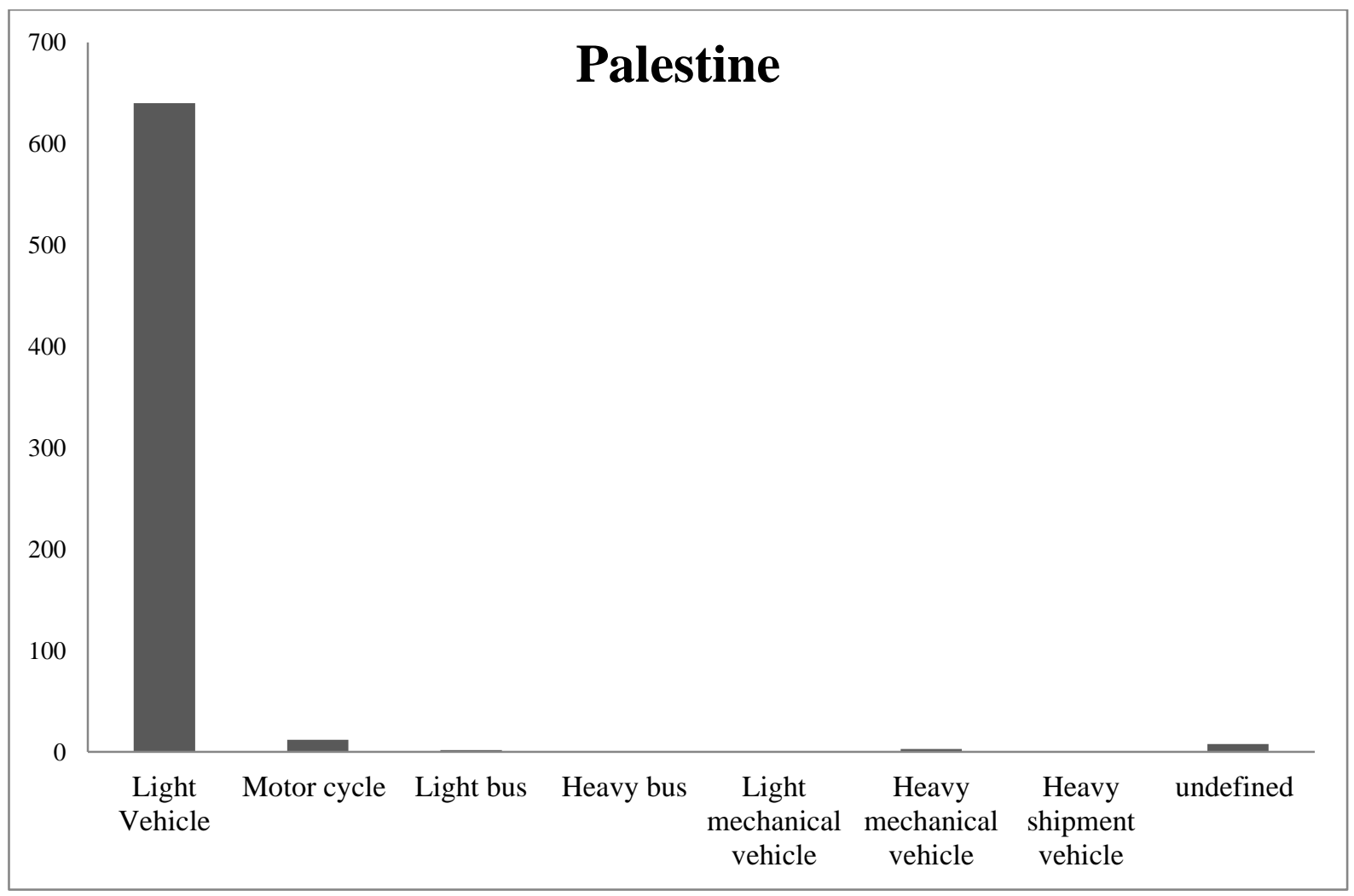

Figure 13 (9). Four years accidents' totals distributed according to citizenship - Palestinian citizenship

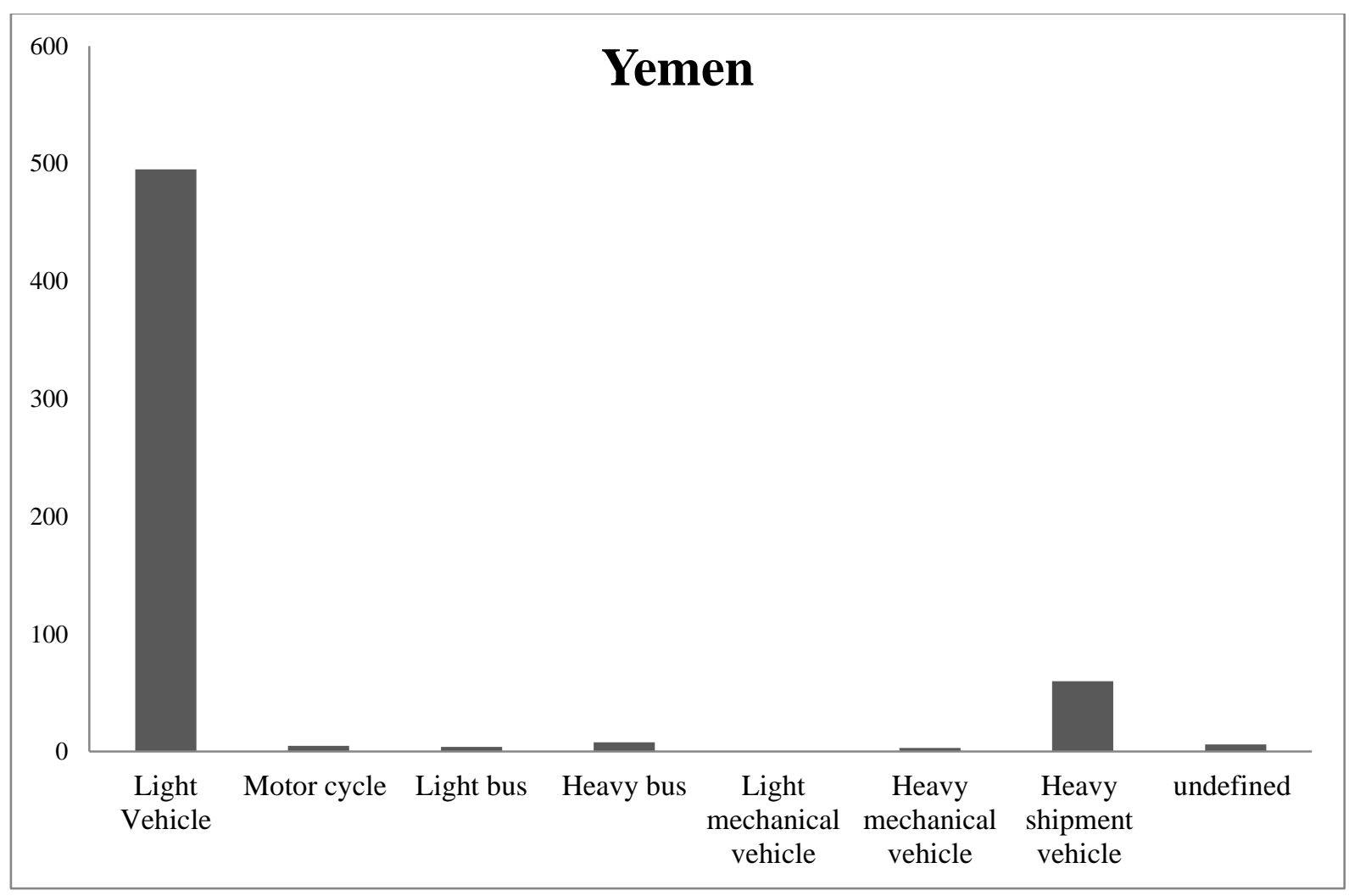

Figure 13 (10). Four years accidents' totals distributed according to citizenship - Yemeni citizenship 


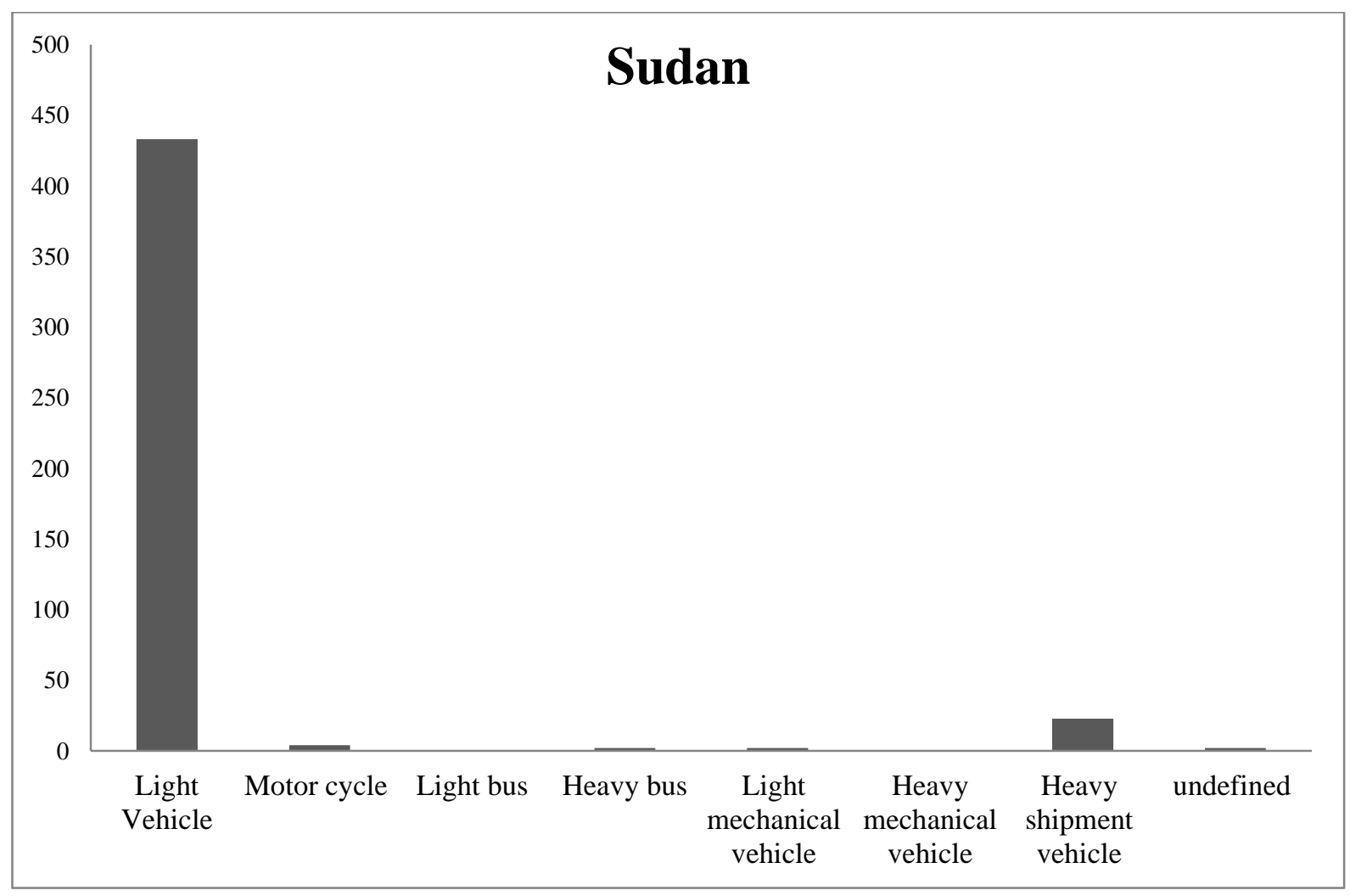

Figure 13 (11). Four years accidents' totals distributed according to citizenship - Sudani citizenship

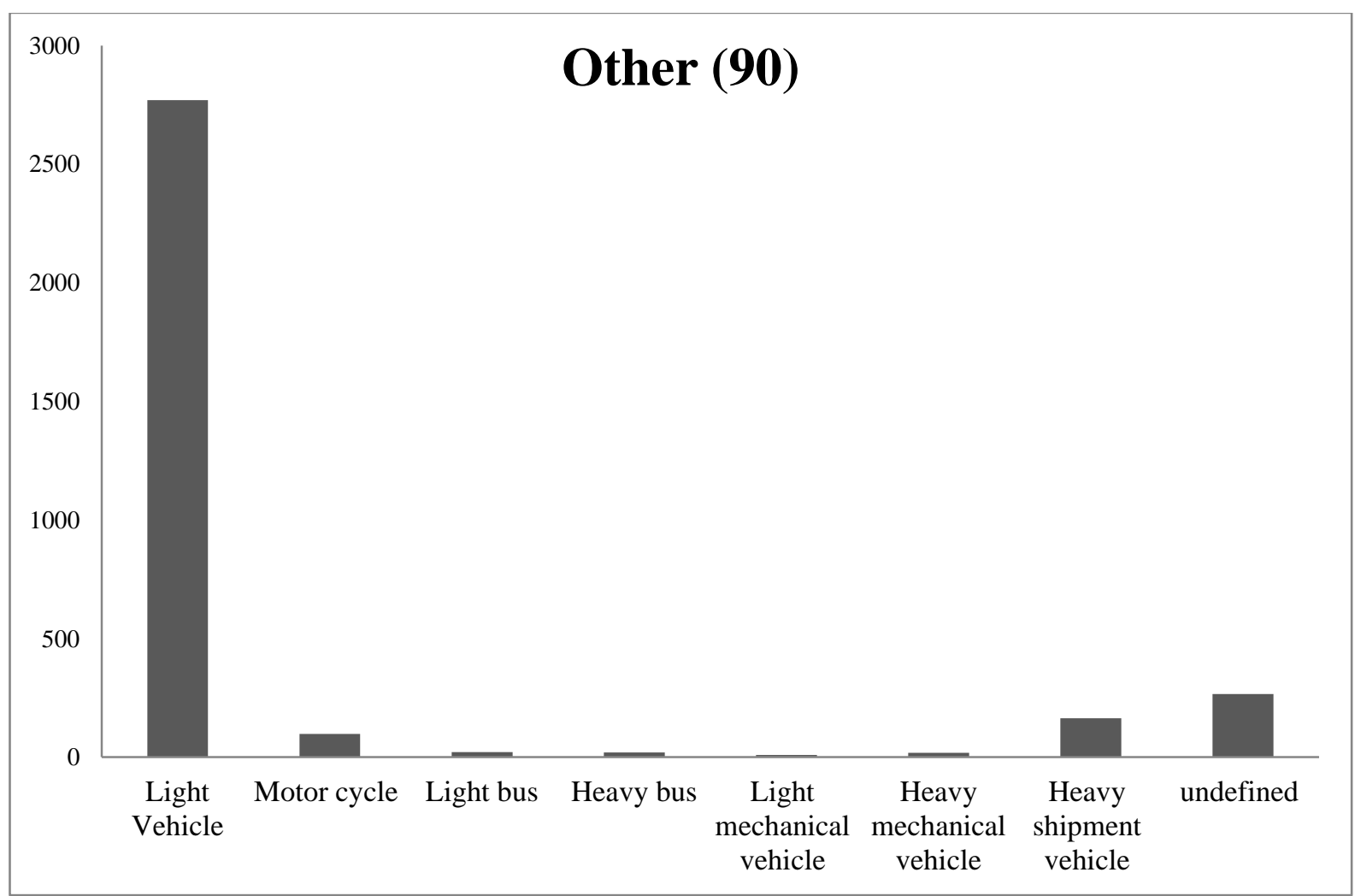

Figure 13 (12). Four years accidents' totals distributed according to citizenship - Other citizenship 


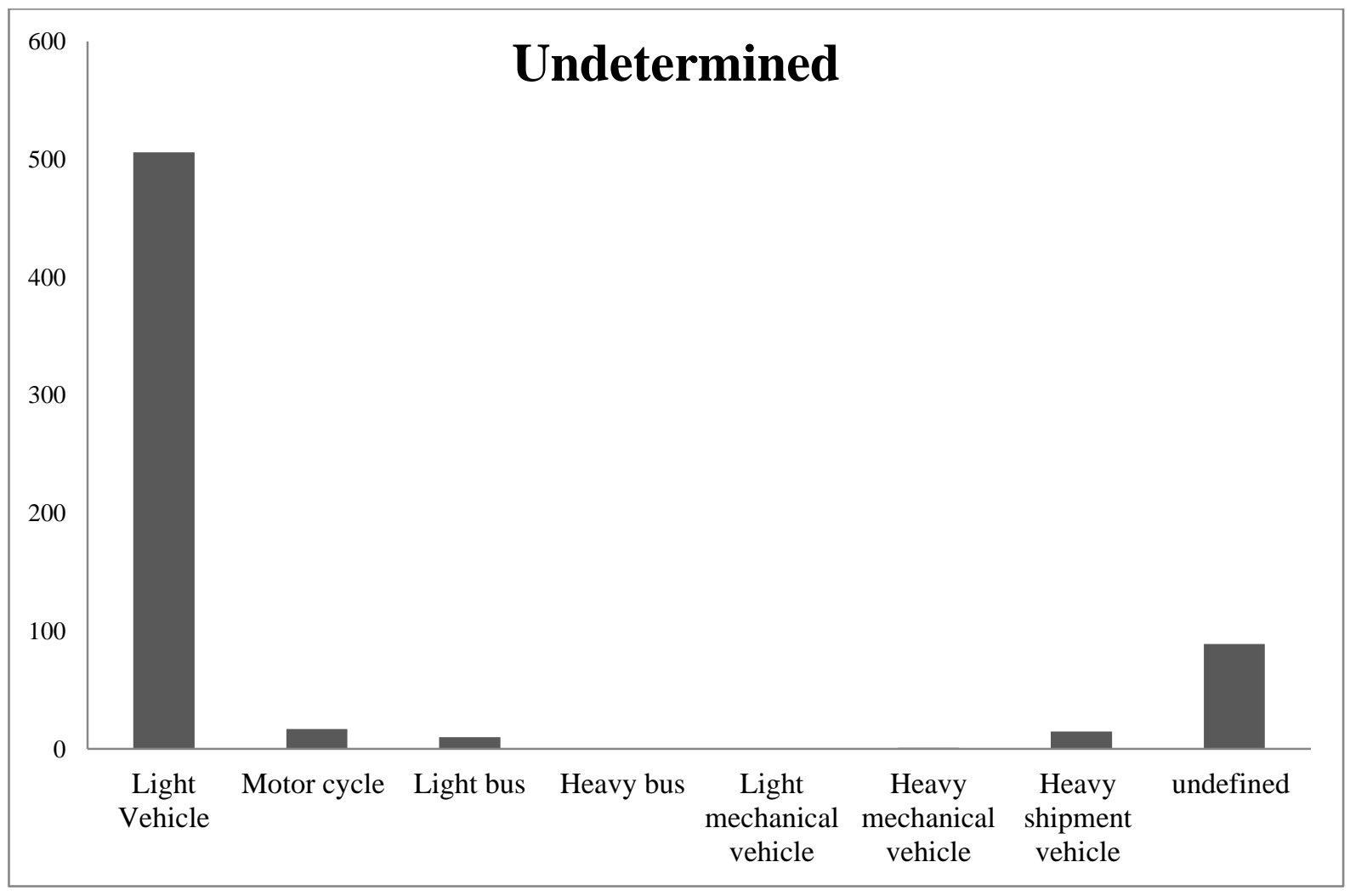

Figure 13 (13). Four years accidents' totals distributed according to citizenship - Undetermined citizenship

\section{Accidents vs. Time and Driver Citizenship}

Also, a further analysis is made based on the traffic accidents statistics for the last four years (2007, 2008, 2009, 2010) for each vehicle type depending on the involved driver citizenship (Figures 14 to 21). For the four years' traffic accidents that are related to the light vehicle type (Figure 14), A general trend can be seen for all citizenships where there is an increase in the number of traffic accidents related to light vehicle type over the course of the first three years followed with a noticeable reduction in the last year (2010) for the major citizenships specifically. The rate of increase for the major citizenships is slower between the years 2008 and 2009 after the implementation of the unified traffic enforcement law compared to the rates of the years 2007 and 2008 .

Figure 15 shows the accidents' 4-years totals for the motorcycle type for all citizenships. The increasing trends in accidents total exist for the major citizenships (Emirates nationals, Pakistanis, Indians, Egyptians, and Bangladeshi) for the years 2007 and 2008. However, for all these major citizenships and after the year 2008, we can see clear reduction after the 
implementation of the unified traffic enforcement law with an exception for the Pakistanis citizenship. For the light bus vehicle types (Figure 16) and for Pakistanis and Indians citizenships there is a tremendous increase in the total traffic accidents over the course of the four years except for the year 2010 for Pakistanis that shows noticeable decrease. For the heavy bus vehicle types (Figure 17) and for both Pakistanis and Indians, the same increasing trend can be seen for the years 2007 to 2009 with a remarkable decrease for the year 2010 for both citizenships. For the heavy shipment vehicle accidents' type (Figure 20), Pakistanis citizenship accidents show permanent increase over the first three years' time span with a reduction in last year (2010) while the Indian citizenship accidents show an increase between 2007 and 2008 then the rate goes down at 2009 and 2010. Similar important relationships for the rest of vehicle types and citizenships can be drawn for the rest of the figures. These remarks can be used to identify the highly involved citizenships and vehicle types in UAE road accidents so more focus can be directed to these categories through reviewing existing traffic laws in a way that ensure more restrict fines on these categories besides working on increasing the traffic safety awareness levels among these targeted groups.

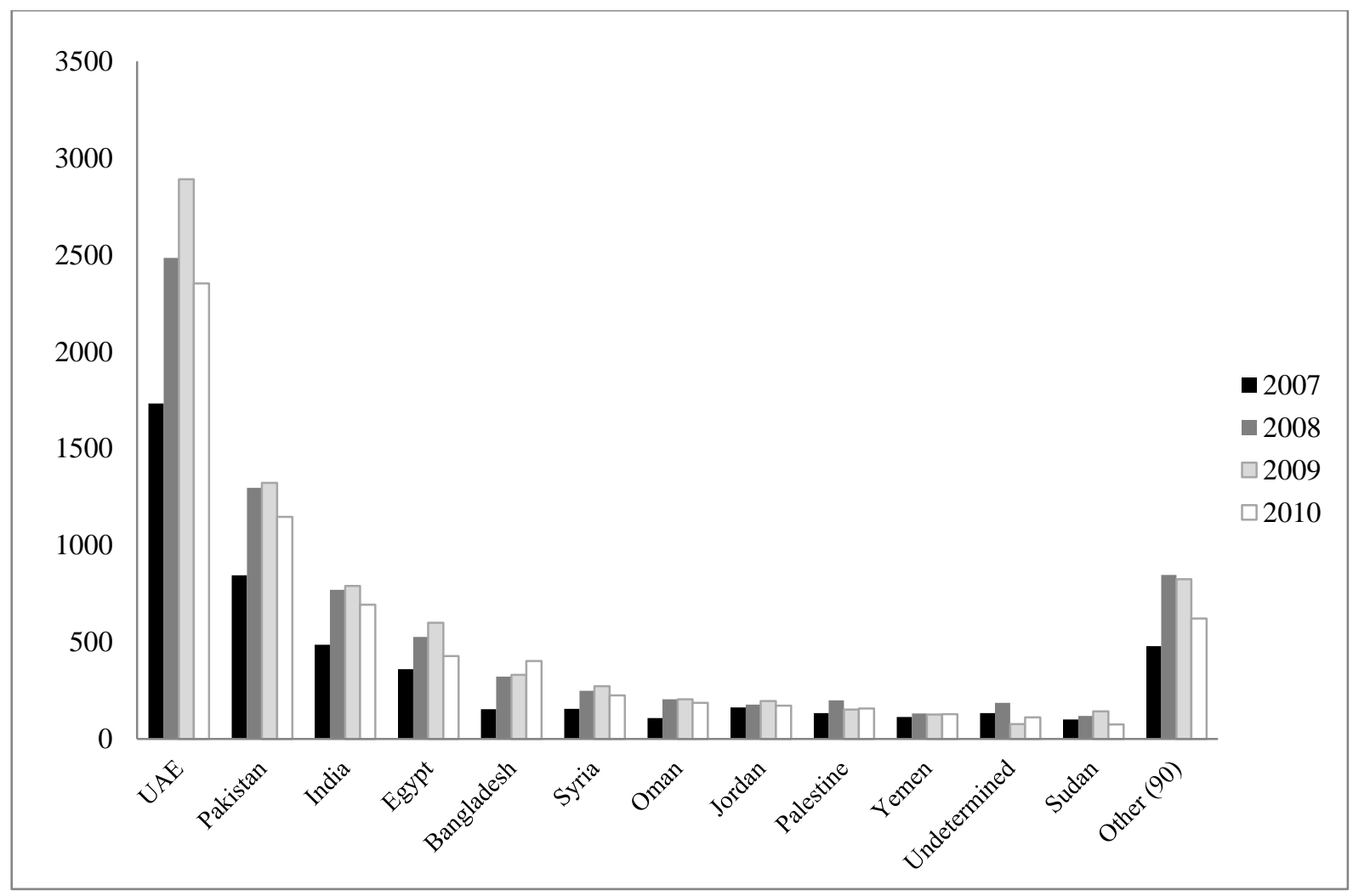

Figure 14. Traffic accidents rates for the last four years $(2007,2008,2009,2010)$ for light vehicle type based on the driver citizenship 


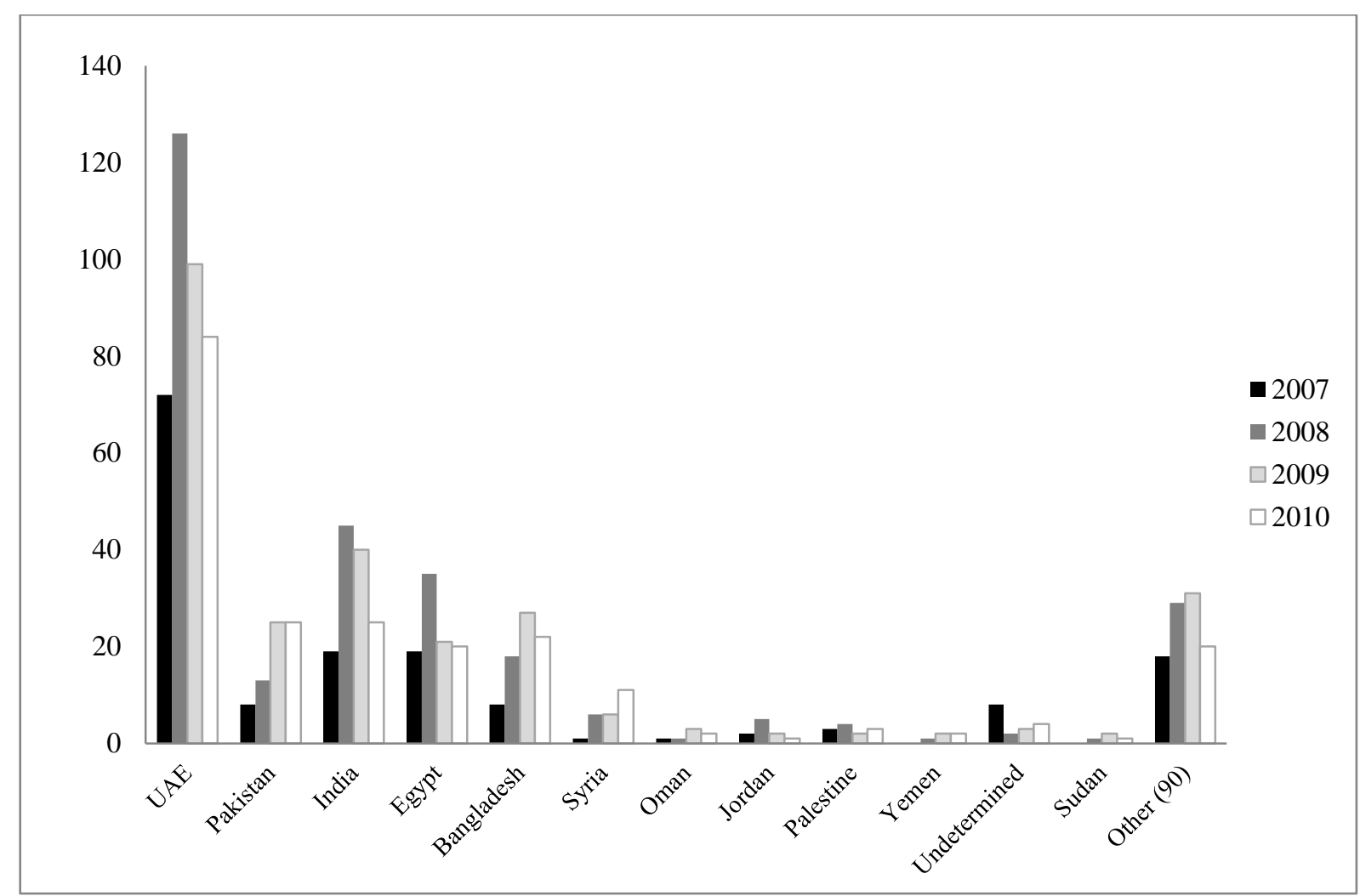

Figure 15. Traffic accidents rates for the last four years $(2007,2008,2009,2010)$ for motorcycle type based on the driver citizenship

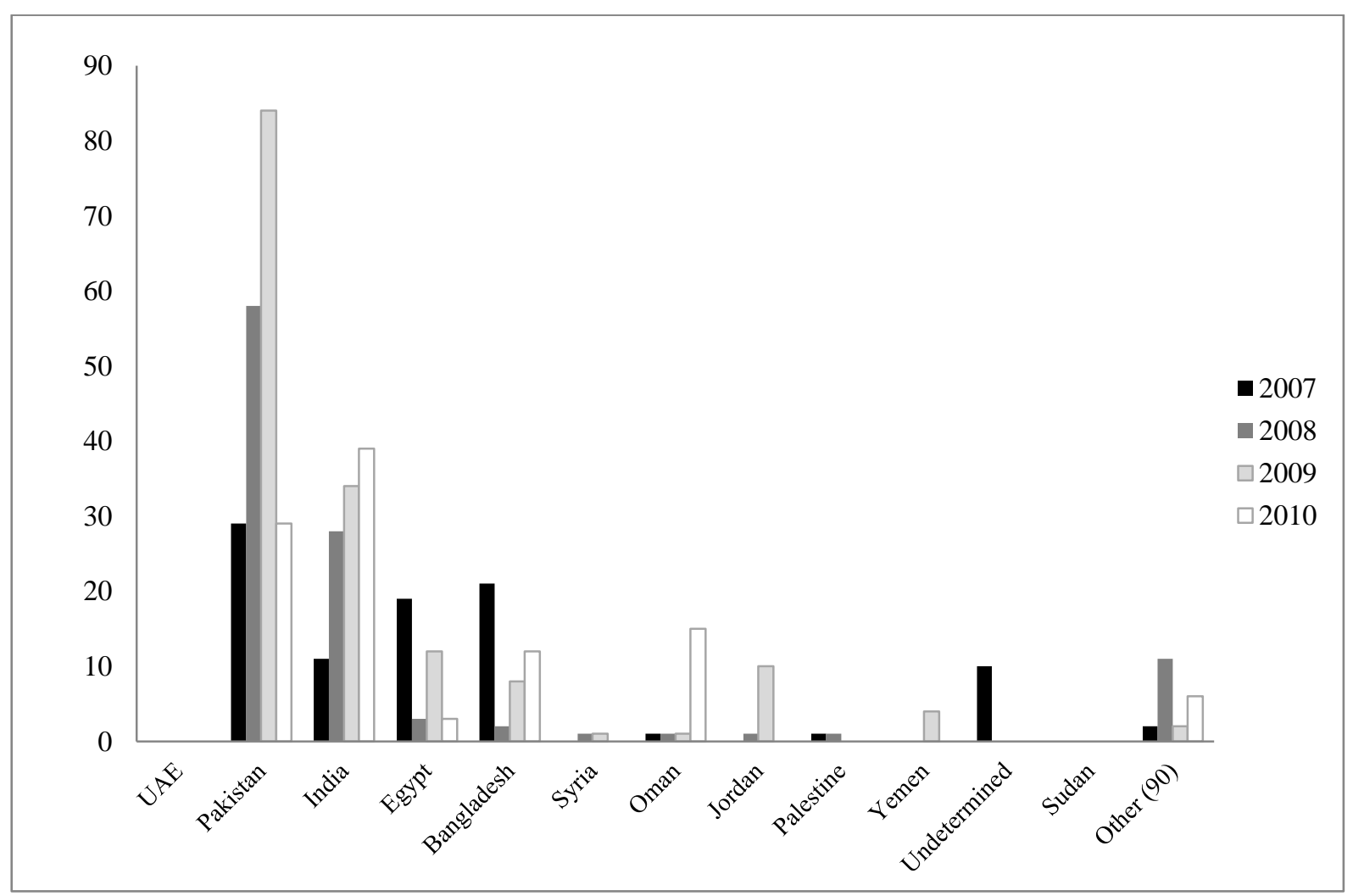

Figure 16. Traffic accidents rates for the last four years $(2007,2008,2009,2010)$ for light bus type based on the driver citizenship 


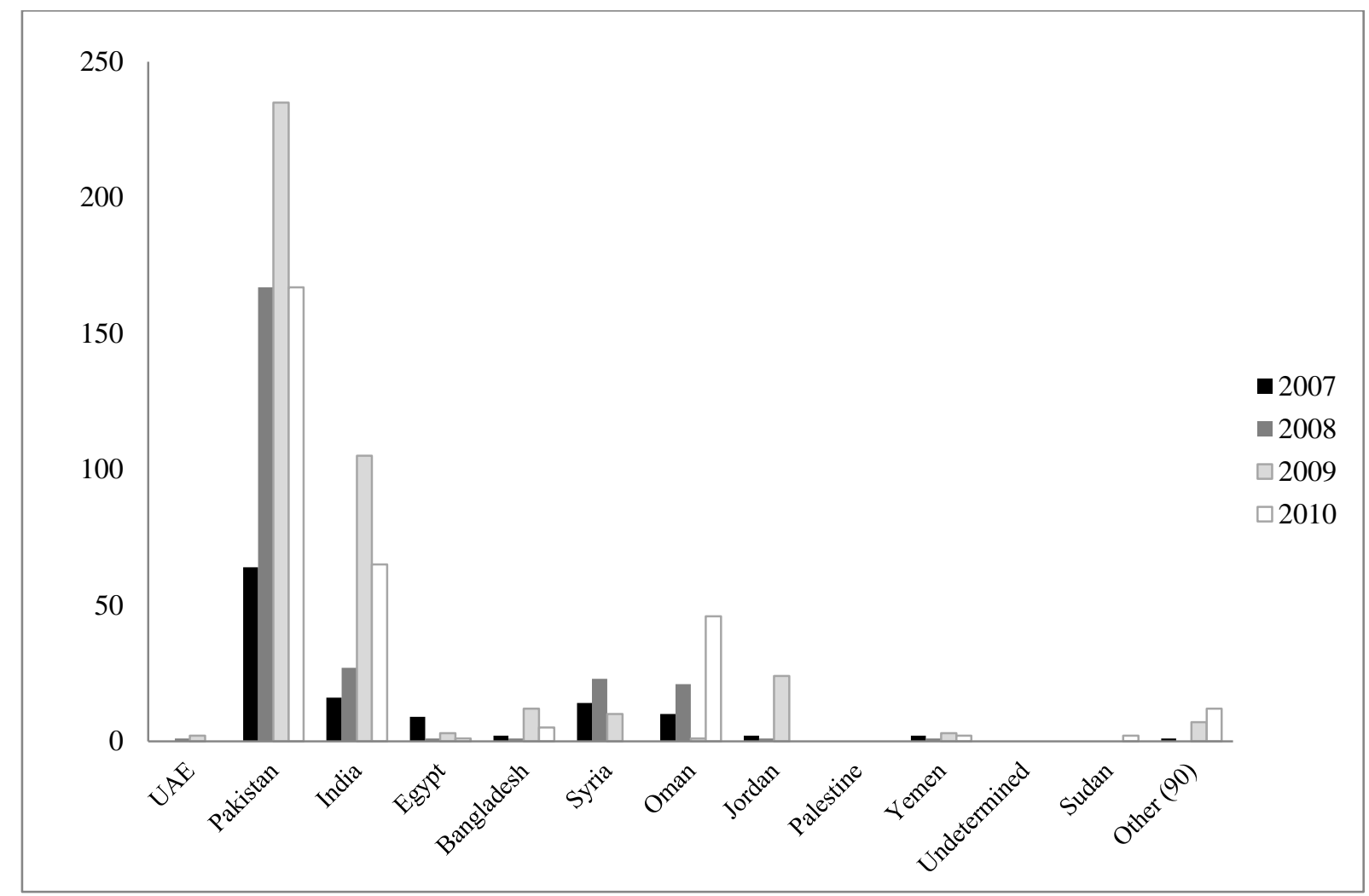

Figure 17. Traffic accidents rates for the last four years $(2007,2008,2009,2010)$ for heavy bus type based on the driver citizenship

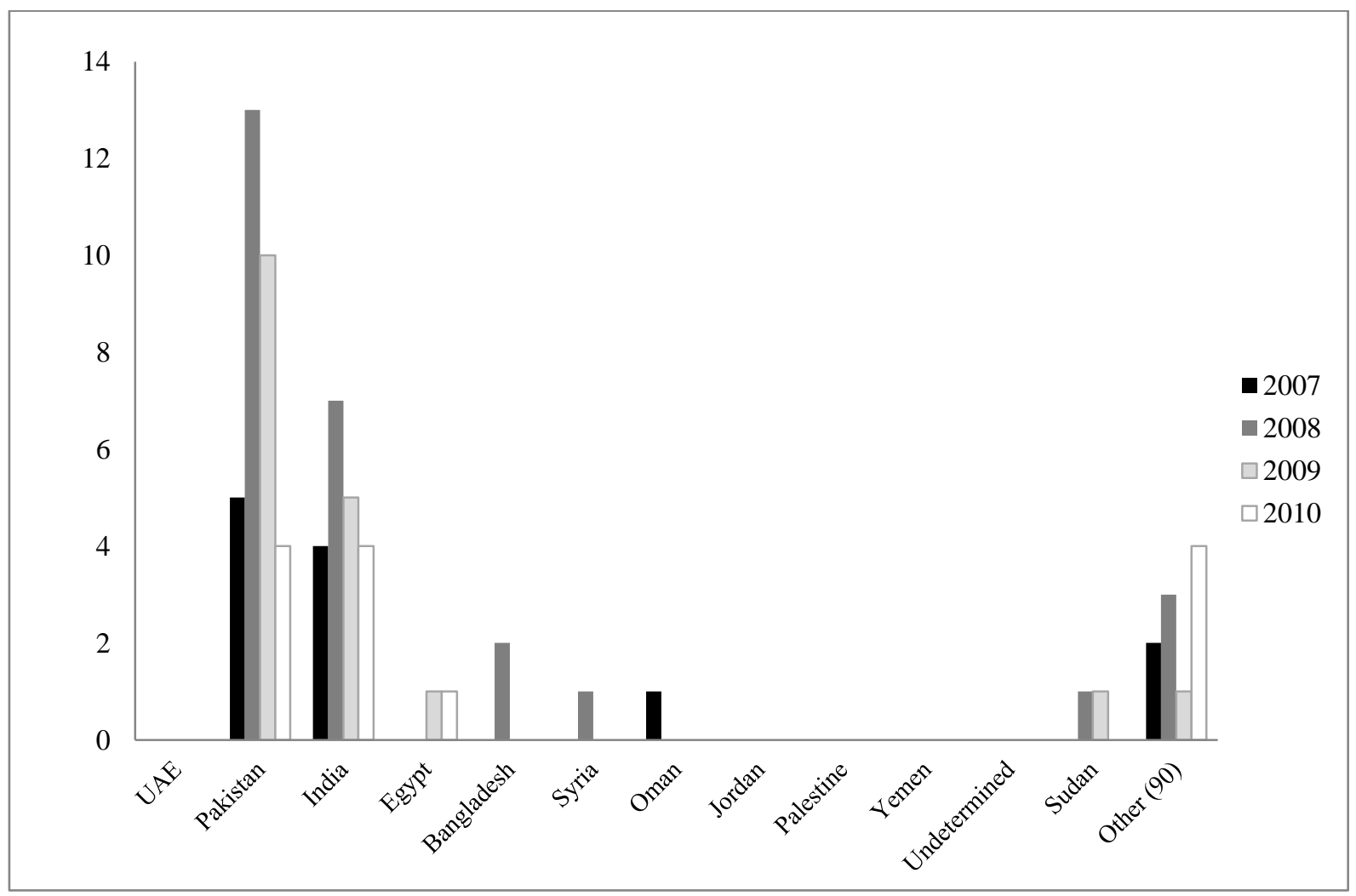

Figure 18. Traffic accidents rates for the last four years $(2007,2008,2009,2010)$ for light mechanical vehicle type based on the driver citizenship 


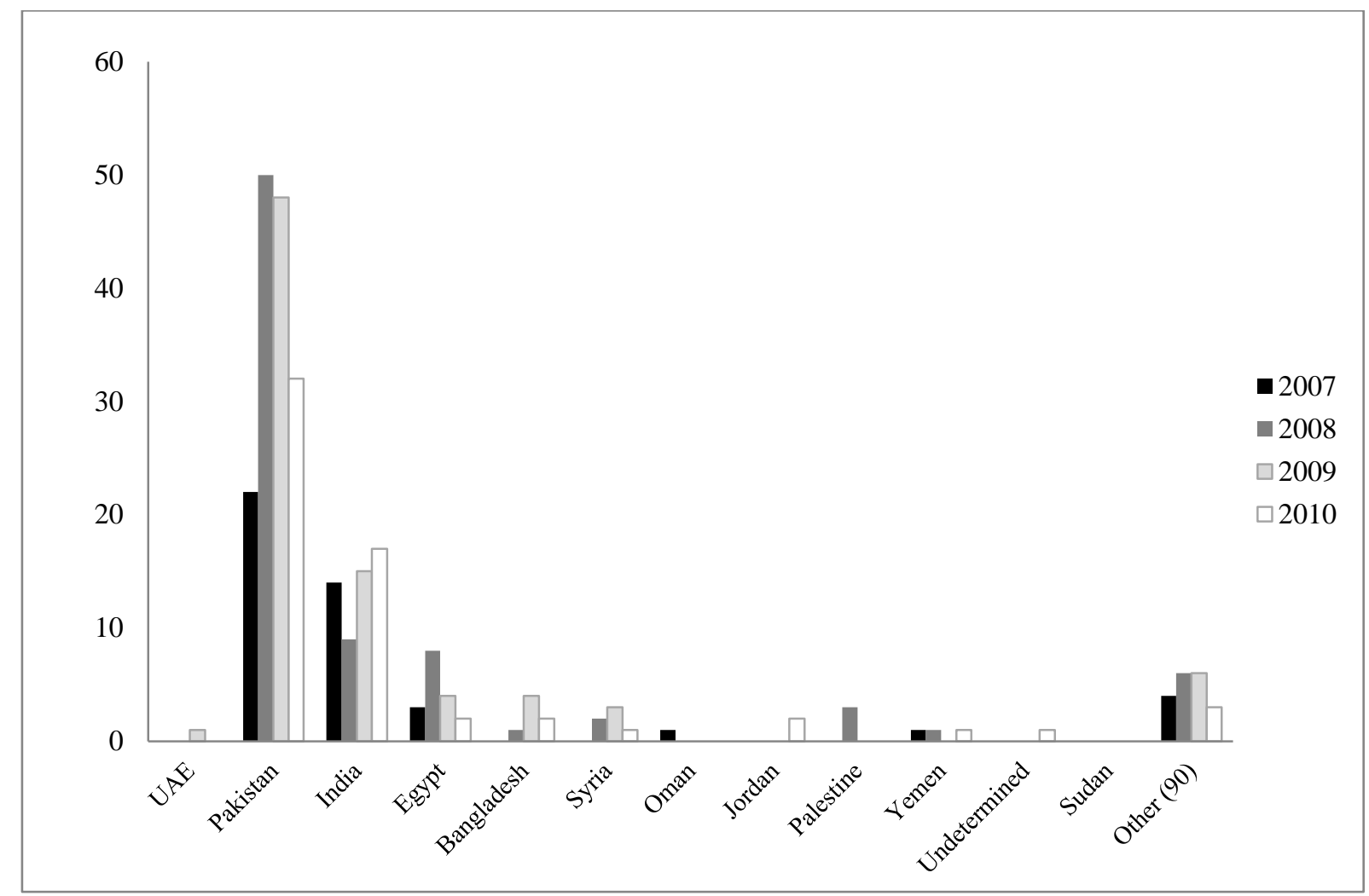

Figure 19. Traffic accidents rates for the last four years $(2007,2008,2009,2010)$ for heavy mechanical vehicle type based on the driver citizenship

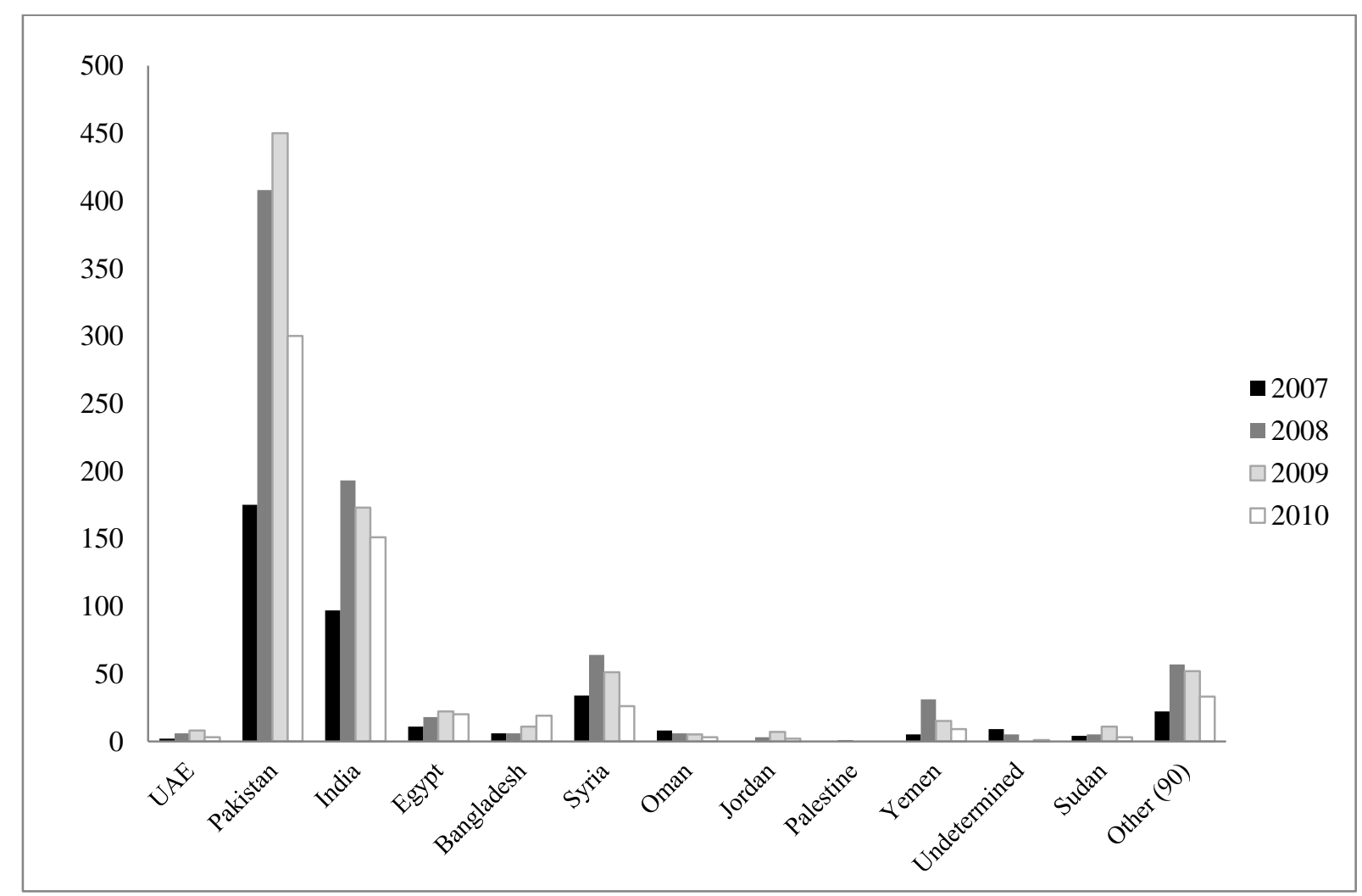

Figure 20. Traffic accidents rates for the last four years $(2007,2008,2009,2010)$ for heavy shipment vehicle type based on the driver citizenship 


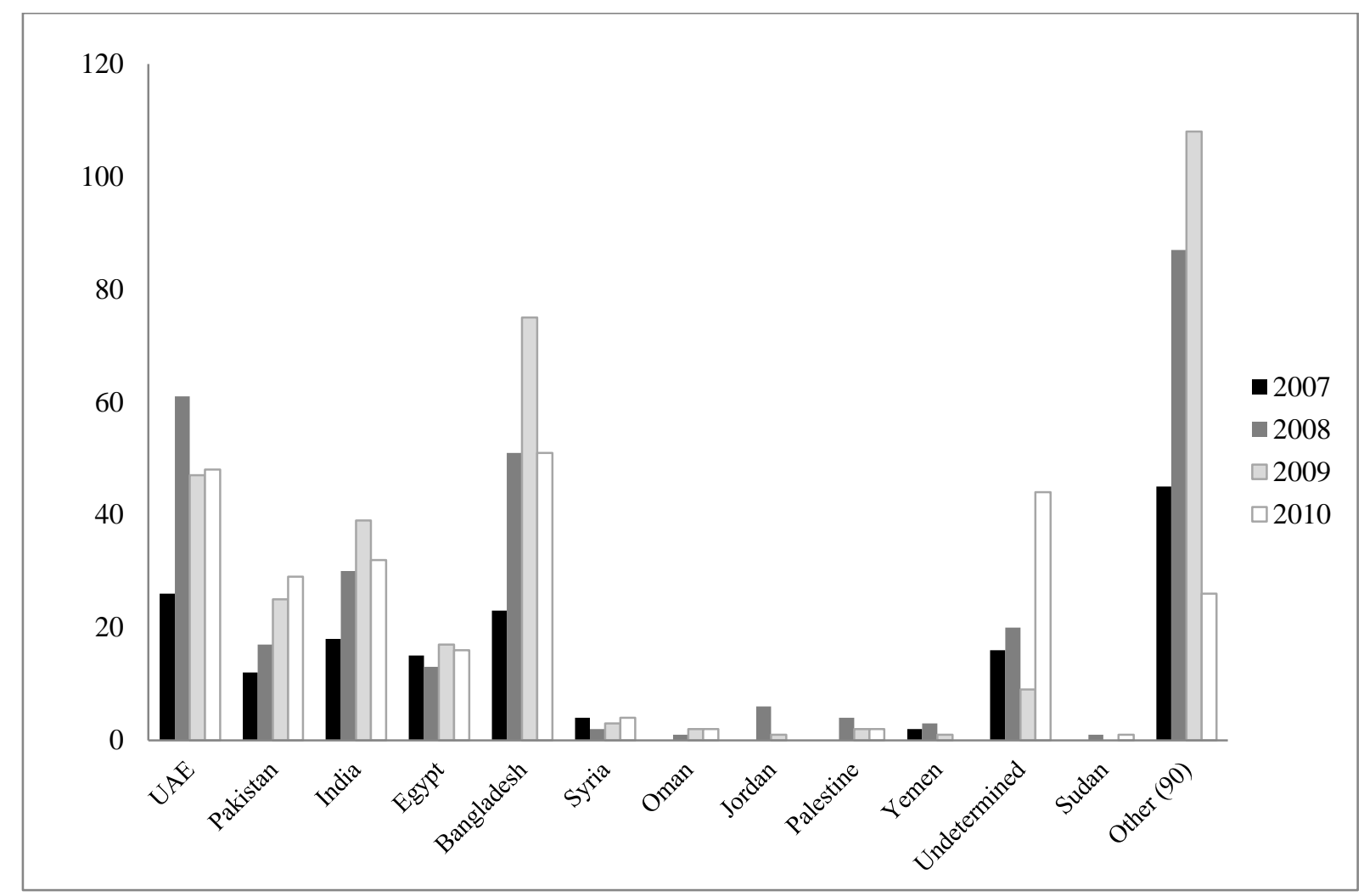

Figure 21. Traffic accidents rates for the last four years $(2007,2008,2009,2010)$ for undefined vehicle type based on the driver citizenship

Currently no statistics are available to describe the average age per nationality. However, work experience in the field can confirm that some citizenships (e.g., Pakistan and India) are associated with higher accident rates because of younger (and less experienced) citizens. This is also true due to the cultural difference and different driving behaviors available at UAE compared to their home countries. 


\section{Conclusion}

Driver has a very important role in traffic accidents and most of the time he/she holds the major responsibility (more than $90 \%$ as per previous research) as he/she has the highest control level on the road. A focus was placed on identifying the relationships that drivers' licensing, drivers' citizenships and vehicle types have with traffic accidents.

Analysis and results obtained reveals a number of important findings. There has been an excessive increase in the number of new driver's licenses issued over the past 11 years where they almost doubled in number in 2009 as compared to that in 2000 (496138 in 2009 while it was 262045 in 2000). Most of these licenses are newly issued licenses. The lack of experience that usually associates new drivers can play a major role in traffic accident occurrence. For fatality associated accidents, results indicate that the average number of licenses associated with each fatality is decreasing over years which indicate that there is an increase in the accident severity (fatality) over time with more cars being involved in these accidents upon their occurrence. A significant increase in the number of fines issued per license can be seen clearly which rises on average from 5 fines/license in 2000 to 13 fines/license in 2009. The major increase happened after year 2008 after the implementation of the unified law which reflects that a stronger traffic enforcement law took place which played a major role in traffic accidents reduction.

Regarding the citizenship of the drivers who are involved in traffic accidents over the last 4 years, results indicated that for all types of vehicles emirates nationals drivers represent the citizenship with the highest involvement rate in traffic accidents (30.02\%) followed by Pakistanis $(21.26 \%)$ then comes the Indians drivers with a percentage of $11.95 \%$. The same result was obtained for the light vehicle accidents, this type of vehicle accidents represent the major portion of all vehicles accidents, where the major contributing citizenships, in descending order according to number of accidents they are involved in, are: emirates nationals (largest contribution), Pakistanis, Indians and Egyptians. This might be interpreted by the fact that emirates nationals own large number of light vehicles. Also for Pakistanis and Indians high contribution to accidents, this can be related to the fact that huge numbers of these citizenships work as drivers (taxi, private...etc) for light vehicles. For motor cyclists' accidents; emirates nationals, Indians, Egyptians, Bangladeshis, and Pakistanis in the given 
order represented the citizenships with the highest contribution to traffic accidents. For industrial and construction vehicles accidents (i.e., light and heavy buses, light and heavy mechanical vehicle, and heavy shipment vehicle), the most contribution to accidents for these types of vehicles is done by Pakistanis and Indians drivers. The fact that Pakistanis and Indians represent the major citizenships that work in these types of industries either in public transportation as drivers, or in construction industries or other heavy industry business can explain this trend.

Light vehicle type traffic accidents statistics for the years $(2007,2008,2009,2010)$ shows that a general trend can be seen for all citizenships where there is an increase in the number of traffic accidents over the course of the first three years followed with a noticeable reduction in the last year (2010) for the major citizenships specifically. The rate of increase for the major citizenships is slower between the years 2008 and 2009 after the implementation of the unified traffic enforcement law compared to the rates of the years 2007 and 2008. The increasing trends in accidents total exist for the major citizenships (Emirates nationals, Pakistanis, Indians, Egyptians, and Bangladeshi) for the years 2007 and 2008. However, for all these major citizenships and after the year 2008, we can see clear reduction after the implementation of the unified traffic enforcement law with an exception for the Pakistanis citizenship. For the light bus vehicle types and for Pakistanis and Indians citizenships there is a tremendous increase in the total traffic accidents over the course of the four years except for the year 2010 for Pakistanis that shows noticeable decrease. For the heavy bus vehicle types and for both Pakistanis and Indians, the same increasing trend can be seen for the years 2007 to 2009 with a remarkable decrease for the year 2010 for both citizenships. For the heavy shipment vehicle accidents' type, Pakistanis citizenship accidents show permanent increase over the first three years' time span with a reduction in last year (2010) while the Indian citizenship accidents show an increase between 2007 and 2008 then the rate goes down at 2009 and 2010. The major contribution of this paper was its uniqueness in analyzing such accidents database after the implementation of the new unified traffic law in UAE. The paper succeeds in identifying those citizenships with major involvement in road accidents in UAE for future remedy. Due to the lack of available statistics, some important aspects such as the age of involved nationality in road accidents couldn't be investigated that will represent our main objective in the future research. 


\section{References}

Asogwa S. E. (1980) Some characteristics of drivers and riders involved in road traffic accidents in Nigeria. East African Medical Journal, vol. 57, pp. 399-404.

Bekibele C., Fawole O., Bamgboye A., Adekunle L., Ajav R., Baiyeroju A. (2007) Risk factors for road traffic accidents among drivers of public institutions in Ibadan, Nigeria, African Journal of Health Sciences, vol. 14, pp. 137-142.

Bener A. and Jadaan K. S. (1992) A perspective on road fatalities in Saudi Arabia. Accident Analysis \& Prevention, vol. 24, pp. 143-148.

Bener A. (2001) Road Traffic Injuries in developing countries: Motor Vehicle Accidents in the United Arab Emirates: Strategies for prevention. Global Forum for Health Research, the 10/90 Gap in Health Research, Forum 5, Geneva, pp. 221-222.

Bener A., Abu-Zidan F., Bensiali A., Al-Mulla A., Jadaan K. (2003) Strategy to improve road safety in developing countries. Saudi Med Journal, vol. 24, pp. 603-608.

Bener A., Crundall D., Haigney D., Benisiali A., Al-Falasi A. (2004) Driver Behavior, Stress, Error and Violations on the Road: A cross-cultural comparison study, 3rd International Conference on Traffic \&Transport Psychology, Nottingham, UK.

Bener A. and Crundall D. (2005) Road traffic accidents in the United Arab Emirates compared to Western countries, Advances in Transportation Studies an international Journal, Section A 6, pp. 5-12.

Gregersen, N. and Bjurulf, P. (1996) Young novice drivers: Toward a model of their accident involvement. Accident Analysis \& Prevention, vol. 28, pp. 229-241.

Horne J. and Reyner L. (2000) Sleep Related Vehicle Accidents, Sleep Research Laboratory, Loughborough University.

Humphries D. (1987) Three South African studies on the relation between road accidents and drivers' vision. Ophthalmic and Physiological Optics, vol. 7, pp. 73-79.

Jadaan K., Bener A., Al-Zahrani A. (1992) Some aspects of road user behaviour in selected Gulf countries. Journal of Traffic Medicine, vol. 20, n. 3, pp. 129-135.

Malhotra V. (1990) Prevention of road accidents-role of health services. Swasth Hind, pp. 92-93.

Szlyk J., Seiple W., Viana M. (1995) Relative effects of age and compromised vision on driving performance. Human Factors, vol. 37, pp. 430-436.

Toczolowski J., Gerkowwicz M., Pracka A., Rycerz H. (1996) Vision defects in two age groups of drivers who caused road accidents. Klinika Oczna, vol. 98, pp. 221-224.

Treat J., Tumbas N., McDonald S., Shinar D., Hume R., Mayer R., Stanisfer R., Castellan N. (1977) Tri-level study of the causes of traffic accidents. Report No. DOT-HS-034-3-535-77 (TAC).

Trivedi A. and Rawal D. (2011) Prevalence of road traffic accidents and driving practices among young drivers. Healthline, vol. 2, n. 2, pp. 72-75. 